\title{
Article
}

\section{Foreign Aid, Terrorism and Growth: Conditional Evidence from Quantile Regression}

Asongu, Simplice A., Nwachukwu, Jacinta C. and Biekpe, Nicholas Available at http://clok.uclan.ac.uk/24771/

Asongu, Simplice A., Nwachukwu, Jacinta C. ORCID: 0000-0003-2987-9242 and Biekpe, Nicholas (2018) Foreign Aid, Terrorism and Growth: Conditional Evidence from Quantile Regression. Annals of Public and Cooperative Economics, 90 (3). pp. 457-486. ISSN 1370-4788

It is advisable to refer to the publisher's version if you intend to cite from the work. http://dx.doi.org/10.1111/apce.12235

For more information about UCLan's research in this area go to http://www.uclan.ac.uk/researchgroups/ and search for <name of research Group>.

For information about Research generally at UCLan please go to http://www.uclan.ac.uk/research/

All outputs in CLoK are protected by Intellectual Property Rights law, including Copyright law. Copyright, IPR and Moral Rights for the works on this site are retained by the individual authors and/or other copyright owners. Terms and conditions for use of this material are defined in the policies page.

\section{CLoK}

Central Lancashire online Knowledge www.clok.uclan.ac.uk

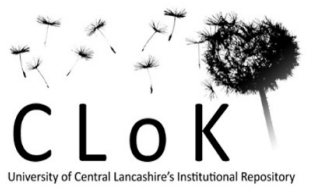




\section{Foreign Aid, Terrorism and Growth: Conditional Evidence from Quantile Regression}

Forthcoming: Annals of Public and Cooperative Economics

\section{Simplice A. Asongu}

Development Finance Centre, Graduate School of Business, University of Cape Town Cape Town South Africa.

E-mail: asongusimplice@yahoo.com

\section{Jacinta Nwachukwu}

Lancashire School of Business and Enterprise, University of Central Lancashire, Preston PR1 2HE, United Kingdom

Email: jcnwachukwu@uclan.ac.uk

\section{Nicholas Biekpe}

Development Finance Centre, Graduate School of Business, University of Cape Town, Cape Town, South Africa

E-mail: nicholas.biekpe@gsb.uct.ac.za 


\title{
Foreign Aid, Terrorism and Growth: Conditional Evidence from Quantile Regression
}

\begin{abstract}
In this study, we investigate the role of development assistance in reducing a hypothetically negative impact of terrorism on economic growth, using a panel of 78 developing nations with data for the period 1984-2008. The empirical evidence is based on interactive Quantile regressions. Domestic, transnational, unclear and total terrorism dynamics are employed while development assistance measurements comprised: bilateral and multilateral aid variables. With regard to the investigated hypothesis, we consistently confirm that: (i) In quantiles where terrorism is found to increase (decrease) economic growth, its interaction with foreign aid decreases (increases) economic growth. (ii) Comparing thresholds of the modifying aid variables for which the hypothesis is either rejected or accepted reveals that higher levels of multilateral (bilateral) aid are needed to reverse the negative effect of total (unclear) terrorism on growth, than the quantity needed to reverse the positive impact of transnational (domestic and total) terrorism(s) on growth. (iii) There is scant evidence of positive net effects. Overall the findings broadly indicate that foreign aid is a necessary but not a sufficient policy tool for completely dampening the effects of terrorism on economic growth.
\end{abstract}

JEL Classification: C52; D74; F23; F35; O40

Keywords: Economic Growth; Foreign aid; Terrorism; Quantile regression 


\section{Introduction}

An April 2015 publication by the World Bank of World Development Indicators has raised renewed interest in policy-making and academic circles (Asongu \& Kodila-Tedika, 2017a). The account maintains that more than 45 percent of Sub-Saharan (SSA) African countries were off-track from achieving the Millennium Development Goals (MDGs) extreme poverty target (Caulderwood, 2015; World Bank, 2015).

The growth that was needed to mitigate poverty at the end of the MDG year was shown to be considerably influenced by political violence and terrorism activities. Consistent with Asongu and Nwachukwu (2016a), countries that have witnessed the Arab Spring have also seen their growth levels plummet, a tendency that is being accompanied with poverty externalities. We may therefore surmise that people who live in a politico-economic environment that is plagued by terrorism have limited access to essential services which are needed to promote growth and wellbeing within an economy. This trend is more rampant in nations that are just emerging from political instability and war. This is primarily because threats of potential terrorism often translate into an economic outlook that is shrouded in uncertainty, owing to a growing concern among both domestic and foreign investors (Kelsey \& le Roux, 2017, 2018). Fundamentally, the impacts of terrorism may be long-lasting involving considerable negative externalities on economic prosperity. Such may include, inter alia: higher insurance premium, growing cost of investment, decreasing economic output, as well as savings and infrastructural damages (Singh, 2001, 2007; Efobi et al., 2015).

Drawing from the 2014 Global Terrorism Index (GTI, 2014, p. 13), terrorism at the global level has been burgeoning since the 2011 Arab Spring. Firstly, post-Gaddafi Libya has become a failed state, with total anarchy, various rebel factions dictating the law of the land and two rival domestic governments claiming control over the economy. Secondly, the situation in Yemen has considerably deteriorated, with a proxy war being fought since early 2015 by Saudi Arabia and Iran supporting the government and rebels respectively. One account for the cause of the ongoing conflict highlights the inability of the government to honour the terms of its socio-economic contract with the Yemeni citizens following the ouster of President Ali Abdullah Saleh. Thirdly, the damaging impact of the persistent attacks by the terrorist group, Boko Haram in northern Nigeria, is felt in neighbouring nations in particular Cameroon, Chad and Niger. Fourthly, externalities of the Syrian conflict have given birth to a very powerful Islamic State of Iraq and the Levant (ISIL) that is having substantial geopolitical effects throughout the world. A few of the most notable examples include (i) 
hostage crisis and shooting in Sydney-Australia in December 2014; (ii) Verviers-Belgium attacks that were foiled in January 2015; (iii) 'Charlie Hebdo' shooting in Paris-France of January 2015 which killed 12 people and injured 11 others, (iv) the series of coordinated mass shootings and a suicide in November 2015 in Paris-France in which the attackers killed 130 people including 90 at the Bataclan theatre with another 413 people injured.

In light of the above, there has been an evolving academic focus on the effectiveness of the various tools with which domestic, transnational and global terrorisms have been tackled. For example, studies documenting the strategies with which the scourge of terrorism could be fought include: transparency (internal and external) (Bell et al., 2014); education by means of bilingualism (Costa et al., 2008); respect of the rule of law (Choi, 2010); press freedom and publicity (Hoffman et al., 2013); education (Brockhoff et al., 2015); the assessment of behaviours towards terrorism (Gardner, 2007) and military mechanisms (Feridun \& Shahbaz, 2010). Lines of inquiry focusing on regional specific assessments (like Africa) have included: the role of lifelong learning on political stability/non-violence (Asongu $\&$ Nwachukwu, 2016b); the fight against corruption being the most effective instrument in the battle against conflicts and crimes (Asongu \& Kodila-Tedika, 2016) and geopolitical movements as the primary characteristic explaining the changing sub-Saharan African warfare landscape (Straus, 2012).

Drawing from the above narratives on (i) the need for growth in poverty mitigation and (ii) the importance of fighting terrorism in order to create an enabling environment for economic growth, this paper assesses how the potentially negative effects of terrorism on economic growth can be mitigated with foreign aid, conditional on initial levels of the growth of output. Before we discuss how these objectives contribute to existing literature, it is important to clearly articulate how the positioning steers clear of discussions in the previous studies. To this effect, we largely involve those articles that addressed a similar line of inquiry. The strand of the literature that fits closest into this narrative is that which has been devoted to investigating relationships among, terrorism, conflicts, political stability and macro economic variables. As far as we know, the available studies have focused on: the effect of terrorism on foreign direct investment (FDI) (Abadie \& Gardeazabal, 2008), the impact of terrorism on innovation (Koh, 2007), dynamics of resource-wealth in conflict management (Humphreys, 2005), linkages between terrorists activities and economic growth (Meierrieks \& Gries, 2013; Choi, 2015) and the role of foreign aid in dampening the negative impact of terrorism on FDI (Bandyopadhyay et al., 2014; Efobi et al., 2015). The last-two stream of 
studies is closest to the present line of inquiry, notably: the instrumentality of foreign aid in reducing the impact of terrorism on macroeconomic variables.

To the best of our knowledge, available studies that have been devoted to the relationship between terrorism and macroeconomic variables can be categorised into three main strands, notably: causality trickling to economic growth from terrorism, the impact of economic growth on terrorism and bidirectional causalities between growth and terrorism.

The first strand embodies three main studies. (1) Gaibulloev and Sandler (2009) which investigated the effects terrorism and conflicts on the growth of per capita income in Asia for the period 1970-2004 to establish that transnational terrorist' attacks weakened growth substantially, by decreasing government expenditure. According to the conclusions, an additional terrorism incident per million people reduced per capita domestic growth by about 1.5 percent. Compared with the more advanced nations, this unappealing impact of terrorism is more pronounced in less developed countries, which cannot tackle the damaging consequences of terrorism without significant adverse economic outcomes. In addition, the negative impact of internal conflicts is twice as high for transnational terrorists' incidents. (2) The effect of terrorism on economic growth across several provinces in Turkey was investigated by Öcal and Yildirim (2010) for the period 1987 to 2001. They concluded that the two variables are negatively correlated, with the adverse effect more pronounced for the Eastern and South Eastern regions compared to the Western provinces. (3) The relationship between terrorism and economic growth was examined by Meierrieks and Gries (2013) for a panel of 160 nations with data from 1970 to 2007. The authors confirmed a relationship that is heterogeneous across time and space. For instance, in the Cold war era, growth was found to have swayed terrorists' activities in countries with intermediate development levels that witnessed terrorism and political instability in Latin America. By contrast, in the post- 'Cold war' era, terrorists' activities have been found to exert more negative economic consequences in African and Islamic countries. This was particularly noticeable in those countries with: (i) high levels of political openness and instability and (ii) experiences of escalating terrorism.

Two main studies constitute the second strand. (1) The effect of terrorism on several economic variables has been assessed by Piazza (2006), namely on: poverty, inflation, inequality, economic performance, malnutrition, as well as political and demographic control indicators. Multiple regressions are performed on 96 nations for the 1986-2012 period. Findings show that, as opposed to the mainstream consensus, the relationships between economic development indicators and terrorism are not significant. However, variables like 
the 'structure of party politics', population, 'ethno-religious diversity' and 'increase state repressions' are established to be significant determinants. The author concluded that the 'social cleavage theory' is more exogenous to terrorism compared to theories advancing that terrorism is the result of poor economic performance. (2) The issue of whether economic growth dampens terrorism was investigated by Choi (2015). The author measured terrorism (economic growth) in terms of domestic, suicide and international indicators (agricultural and industrial sectors). The study proposed a modified theory of hard targets to assess if wealthy industrial countries with relatively poor agricultural productivity are more likely to witness suicide attacks. The empirical evidence which is based on a panel of 127 countries for the 1970-2007 period confirmed that countries that enjoy higher levels of industrial growth are less likely to witness domestic and international terrorist attacks, but more prone to suicides. .The results show that economic development is not an entire cure for terrorism though it is effective in mitigating terrorism because the reported suicide attacks were observed largely in a few countries.

The third strand which focuses on bidirectional causalities between terrorism and economic growth is articulated by three main studies. (1) The causality between economic growth and terrorism was examined by Gries et al. (2011) in seven Western European countries. Whereas from a bivariate perspective, the impact of economic performance on domestic terrorism is substantial, within a trivariate framework, the influence of economic performance on domestic terrorism decreases. The results show that, in three of the seven countries investigated, economic performance caused terrorism actions whereas, no significant evidence of causality was found to flow from terrorism to economic growth within trivariate and bivariate perspectives. (2) The causal relationship between terrorism and economic growth was investigated by Shahbaz et al. (2013) for the period 1973-2010, in Pakistan. The authors employed capital and trade openness in a production function to conclude that: (i) economic growth Granger causes terrorism; (ii) there is a feedback effect between terrorism and trade openness and (iii) the relationship between terrorism and capital is bidirectional. (3) Co-integration and causal relationships among economic growth, FDI and terrorism have been assessed by Shahzad et al. (2015) in Pakistan using quarterly data for the period 1988-2010. Two sub-samples are employed, namely: pre-‘9/11'(1988-2001) and post'9/11'(2002-2010) samples. The results reveal a long-run cointegration among FDI, terrorism and economic growth. Findings of Granger causality show bidirectional short- and long-term 
causalities between economic growth and FDI for both sub-samples. In addition, terrorism is found to have a negative impact on FDI.

The above literature leaves space for improvement in at least three dimensions, notably the: need for exploring more dynamics of terrorism, relevance of growth conditionalities and role of foreign aid as modifying policy variable. First, consistent with Choi (2015), it is appropriate to use a multitude of variables when assessing the relationship between growth and terrorism. This is primarily because the author established that the influence of a plethora of political violence and conflict indicators varied considerably over time and space. Therefore, we follow Efobi et al. (2015) by employing four terrorism indicators. They are: transnational, domestic, unclear and total terrorisms. Second, conditioning the investigated interconnections on growth levels is important because blanket policies in boosting economic growth may not be effective unless they are contingent on initial growth levels and tailored differently across high-growth and low-growth nations. Consistent with the empirical evidence provided by Öcal and Yildirim (2010), the impact of terrorism on economic growth is contingent on cross-regional growth levels. We employ a quantile regression technique that is consistent with this contribution because, it enables an assessment of the determinants of a dependent variable throughout the conditional distributions of the dependent variable. Third, drawing from the evidence that the consequences of terrorism are global, we further condition the analysis with a modifying foreign aid policy variable. Such enables the assessment of how development assistance can be used to dampen the potentially negative impact of terrorism on economic growth. This third contribution informs policy on the appropriate levels of bilateral and multilateral aid essential for achieving the underlying research objectives. The motivation for using foreign aid as a moderating variable is consistent with a recent stream of terrorism literature on the use of development assistance to: (i) mitigate the impact of terrorism on FDI (Bandyopadhyay et al., 2014) and (ii) alleviate the potentially damaging effect of terrorism on FDI conditional on existing corruption-control levels in recipient nations (Efobi et al., 2015).

Drawing from the above narratives, the present line of inquiry assesses how development assistance could be employed to mitigate the possibly damaging effects of terrorism on economic growth, using a panel of 78 developing countries for the period 19842008. The scope of the study is on developing nations because: (i) Gaibulloev and Sandler (2009) have established that negative impacts of terrorist activities are more pronounced in developing nations relative to their developed counterparts. These high income countries have 
been shown to withstand terrorism without experiencing substantial disruptions in their economy and (ii) foreign aid is donated by developed countries to their less developed counterparts.

We briefly discuss the theoretical underpinnings on which our line of inquiry is based. According to Akinwale (2010, p. 125), studies focusing on the resolution of terrorism and conflicts have been considerably based on the Conflict Management Model put forward by Thomas-Kilman and the Social Control Theory Model from Black. On the one hand, with regard to the latter, the connections among groups, individuals and organisations influence the exercise of one of the five fundamental mechanisms of social control, notably: avoidance, negotiation, settlement, self-help and tolerance. On the other, the former have advanced strategic intentions that can very probably surround a two-factor matrix (of cooperation and assertiveness) which when combined with collaboration, induces five main conflict management styles. These are: competition, avoidance, accommodation, collaboration and compromise. The account of Akinwale is in accordance with the literature on conflict management, among others: Volkema and Bergmann (1995), Borg (1992), Black (1990) and Thomas (1992).

The highlighted theoretical foundations are in line with the focus of the current study in the view that, foreign aid which is employed as the policy variable is intuitively designed to capture our hypothesised conditions of conflicts management and social control. In principle, development assistance is intuitively expected to facilitate, inter alia: compliance with the rule of law, enhance education, encourage social responsibility and increase government expenditure in recipient countries. Accordingly, as we have noted earlier, Gaibulloev and Sandler (2009) confirmed that terrorism has the potential for lessening economic growth by crowding-out government expenditure. For brevity and lack of space, we invite the interested reader to find more insights from the vast literature on the positive effects of the other factors (including education, respect for the rule of law and social responsibility) on political stability and non-violence (Heyneman, 2002; Beets, 2005; Heyneman, 2008ab; Oreopoulos \& Salvanes, 2009; Asongu \& Nwachukwu, 2016b, 2015). For instance, Asongu and Nwachukwu (2015) had concluded that foreign aid improves education and lifelong-learning and in a subsequent study, they established that education and lifelong-learning decrease political instability and violence (Asongu \& Nwachukwu, 2016b). Hence, the testable hypothesis of the study is straightforward and clearly stated. It is that development assistance 
plays an important role in reducing a possibly damaging impact of terrorism on economic growth.

The rest of the study is structured as follows. Section 2 describes the data and methodology. The empirical results and policy implications are discussed in Section 3. Section 4 concludes with recommendations for policies and direction for future research.

\section{Data and Methodology}

\subsection{Data}

In accordance with the underlying literature (Bandyopadhyay et al., 2014; Efobi et al., 2015; Asongu, 2015a), we investigate a panel of $78^{1}$ developing nations with data for the period 1984-2008 that is composed of three-year non-overlapping intervals. Hence, all the variables are three-year data averages. The choice of periodicity and sample size are based on: (i) foreign aid data availability, (ii) constraints on the other variables that enter into the empirical specifications and (iii) the need to compare results with studies in the literature that have employed the same periodicity. On the second point, the starting year is 1984 because institutional indicators from the International Country Risk Guide (ICRG) dataset are available only from that year, while with regard to the third point, the interest of 2008 as the ending year is to enable some comparison with previous studies, in the same strand, notably: Bandyopadhyay et al. (2014), Efobi et al. (2015) and Asongu (2015a).

While, the dependent variable is the GDP growth rate, the main independent variable involves four terrorism dynamics. They are: domestic, unclear, transnational and total terrorisms. Terrorism is defined in this study as the actual and threatened use of force by subnational actors with the purpose of employing intimidation to meet political objectives (Enders \& Sandler, 2006). Collectively, these terrorism variables capture the number of yearly incidents registered in a country. In order to prevent mathematical concerns relating to logtransforming zeros on the one hand and correcting for the positive skewness in the dataset, the

\footnotetext{
${ }^{1}$ The sample includes the following developing countries: "Albania, Costa Rica, India, Namibia, Syria, Algeria, Cote d'Ivoire, Indonesia, Nicaragua, Tanzania, Angola, Dominican Republic, Iran, Niger, Thailand, Argentina, Ecuador, Jamaica, Nigeria, Togo, Bahrain, Egypt, Jordan, Pakistan, Trinidad and Tobago, Bangladesh, El Salvador, Kenya, Panama, Tunisia, Bolivia, Ethiopia, Lebanon, Papua New Guinea, Turkey, Botswana, Gabon, Libya, Paraguay, Uganda, Brazil, Gambia, Madagascar, Peru, Uruguay, Burkina Faso, Ghana, Malawi, Philippines, Venezuela, Cameroon, Guatemala, Malaysia, Saudi Arabia, Vietnam, Chile, Guinea, Mali, Senegal, Yemen, China, Guinea-Bissau, Malta, Sierra Leone, Zambia, Colombia, Guyana ,Mexico, South Africa, Zimbabwe, Congo, D. Republic, Haiti, Morocco, Sri Lanka, Congo Republic, Honduras, Mozambique and Sudan".
} 
study takes the natural logarithm of terrorism incidents by adding one to the base. This transformation approach is consistent with recent literature (Choi \& Salehyan, 2013; Bandyopadhyay et al., 2014; Efobi \& Asongu, 2016; Asongu et al., 2018a, 2018b; Asongu \& Nwachukwu, 2018).

Terrorism-specific definitions are from Efobi et al. (2015, p. 6). Domestic terrorism "includes all incidences of terrorist activities that involve the nationals of the venue country: implying that the perpetrators, the victims, the targets and supporters are all from the venue country" (p.6). Transnational terrorism is "terrorism including those acts of terrorism that concern at least two countries. This implies that the perpetrator, supporters and incidence may be from/in one country, but the victim and target is from another". Unclear terrorism is that, "which constitutes incidences of terrorism that can neither be defined as domestic nor transnational terrorism" (p.6). Total terrorism is the sum of domestic, transnational and unclear terrorisms.

Two foreign aid modifying variables are employed in the interactive regressions: bilateral and multilateral aids. The control variables are: infrastructure, trade openness, inflation, political globalisation, exchange rate and internal conflicts. These control variables have been substantially documented in the economic growth literature (Klobodu \& Adams, 2016; Nyasha \& Odhiambo, 2017; Alagidede \& Muazu, 2018; Kumi et al., 2017; Assefa \& Mollick, 2017). The adopted variables which are also in accordance with Efobi et al. (2015) and Bandyopadhyay et al. (2014) are defined in Table 1. We expect 'increasing exchange rate', 'trade openness' and 'infrastructural development' to positively affect economic growth, whereas, the effect of inflation and civil/internal conflicts should be negative. The impact of political globalisation is mixed and cannot be established beforehand because, globalisation has been found to exert both negative and positive impacts, contingent on the leverage a country has in 'decision making' processes at the international level (Asongu, 2014a). Consistent with Rodrik (2008), high exchange rates are positive to economic growth, with the effect more apparent in developing nations. Infrastructural development and trade openness have been substantially documented to boost economic growth (Asongu, 2015a). Naturally, we expect high inflation to mitigate economic growth prospects due to, inter alia: (i) decreasing investment because of a negative economic outlook and (ii) falling consumption from a reducing purchasing power. From intuition, civil or internal conflicts should not be favourable for economic growth. For the purpose of standardization and 
comparability, with the exception of the index of internal civil conflicts, all the predictors of the outcome variables are log-normalized. This is summarized in Appendix 1.

\section{"Insert Table 1 here"}

Table 2 shows the summary statistics of the variables employed in the study. Some of the indicators are defined in logarithm terms in order to facilitate the comparison of mean values. We also notice that there is a substantial variation in the indictors, meaning that, we can be confident that significant estimated relationships would emerge. Table 3 informs us on the potential issues of overparameterization and multicollinearity. These are highlighted in bold. As expected, foreign aid and terrorism variables are highly correlated among themselves, respectively. Therefore, we avoid using more than two terrorism or foreign aid variables in the same specification. We also notice that the dependent variable is negatively (positively) correlated with the terrorism (foreign aid). Hence, our motivation to investigate the effectiveness of foreign aid in dampening the potentially damaging effect of terrorism on GDP growth is based on solid theoretical grounds.

"Insert Table 2 here"

"Insert Table 3 here"

\section{2. Methodology}

In accordance with the underlying literature on conditional determinants (Billger \& Goel, 2009; Asongu, 2013a), we employ a quantile regression (QR) approach in order to investigate if existing levels in economic growth affect the relationship between terrorist incidents and/or foreign aid on growth in developing countries. It involves an evaluation of the impact of selected determinants throughout the distribution of economic growth (Keonker \& Hallock, 2001; Tchamyou \& Asongu, 2017; Boateng et al., 2018).

By contrast, previous studies (see for example Asongu 2015a) focused on parameters estimated at the conditional mean of on economic growth. While conditional mean effects are worthwhile in certain cases, we extend the work carried out in these earlier studies by using QR to distinguish between the impacts of initial levels of economic growth throughout the distribution. For instance, whereas Ordinary Least Squares (OLS) assumes that economic 
growth and error terms are distributed normally, the QR approach is not based on the same normally distributed residuals. Therefore, the techinque enables us to assess the effect of terrorism on economic growth with particular emphasis on best- and worst-performing nations in terms of economic growth in developing nations. In essence, with QR, parameter estimates are derived at multiple points of the conditional distributions of economic growth (Koenker \& Bassett, 1978). The QR technique is increasingly being employed in development literature, inter alia: corruption (Billger \& Goel, 2009; Okada \& Samreth, 2012) and health studies (Asongu, 2014b).

The $\theta$ th quantile estimator of economic growth is obtained by solving for the following optimization problem, which is presented without subscripts in Eq. (1) for the purpose of simplicity and ease of presentation.

$$
\min _{\beta \in R^{k}}\left[\sum_{i \in\left\{i: y_{i} \geq x_{i^{\prime} \beta}\right\}} \theta\left|y_{i}-x_{i^{\prime}} \beta\right|+\sum_{i \in\left\{i: y_{i}<x_{i}^{\prime} \beta\right.}(1-\theta)\left|y_{i}-x_{i^{\prime}} \beta\right|\right],
$$

where $\theta \in(0,1)$. As opposed to OLS which is fundamentally based on minimizing the sum of squared residuals, with $\mathrm{QR}$, the weighted sum of absolute deviations are minimised for various quantiles such as the $25^{\text {th }}$ or $75^{\text {th }}$ (with $\theta=0.25$ or 0.75 respectively) by approximately weighing the residuals. The conditional quantile of economic growth or $y_{i}$ given $x_{i}$ is:

$$
Q_{y}\left(\theta / x_{i}\right)=x_{i^{\prime}} \beta \theta
$$

where unique slope parameters are modelled for each $\theta$ th specific quantile. This formulation is analogous to $E(y / x)=x^{\prime} \beta$ in the OLS slope where parameters are investigated only at the mean of the conditional distribution of GDP growth. For the model in Eq. (2) the dependent variable $y_{i}$ is the GDP growth indicator while $x_{i}$ contains a constant term, trade, inflation, infrastructure, exchange rate, political globalisation and civil/internal conflicts.

The specifications in Eq. (1) are tailored to mitigate the multicollinearity and overparameterization issues identified in Table 3.

\section{Empirical Analysis}

\section{1 Presentation of results}

Tables 4 and 5 present empirical findings corresponding to bilateral aid and multilateral aid respectively. Both tables are sub-divided into two panels. While Panel A 
presents results for domestic and transnational terrorism, Panel B shows the findings of unclear and total terrorisms. Consistent with the discussion in the motivation of the study, the baseline specification is grounded on OLS in order to emphasise the differences in our modelling techniques when a distinction is made between the mean and conditional values of GDP growth. The superiority of using QR is consistently evident from the disparities in significance and magnitude of estimated coefficients between the OLS and QR findings. In line with Brambor et al. (2006), the overall impact of the modulating foreign aid variable on the investigated relationship is examined in terms of marginal impacts.

The following findings can be established from Table 4 on the associations among GDP growth, bilateral aid and terrorism. First, the effect of domestic terrorism on GDP growth is marginally significant at the median while the impact of 'transnational terrorism' is not. In Panel B, 'unclear terrorism' mitigates economic growth only in the bottom quantiles of the distribution while 'total terrorism' has a positive effect at the median point. Second, the effect of foreign aid on the dependent variable is positive in a wave-like pattern: initially increasing, then decreasing and later increasing from the bottom to the top quantiles of the distributions. This pattern is consistent with the Left-Hand-Side (LHS) and Right-Hand-Side (RHS) of both panels.

Third, contrary to the intuition motivating our study, the interaction between foreign aid and terrorism does not increase economic growth as expected. By contrast, we found that, in quantiles where terrorism is shown to increase (decrease) economic growth, its interaction with foreign aid decreases (increases) economic growth. Hence; (i) on the LHS of Panel A for 'domestic terrorism and bilateral trade', result for the median are in conflict to our original perception and (ii) on the RHS of Panel B, for 'total terrorism and bilateral aid', the findings of the median are also in contrast to our proposition. Fortunately, on the LHS of Panel B, for 'unclear terrorism and bilateral aid', the results are in line with our expectations at the $25^{\text {th }}$ quantile. The thresholds of the modifying bilateral aid are within the range of ' 0.765 to 8.362 ' provided by the summary statistics for all three cases, respectively: (i) $5.4(0.027 / 0.005)$ for the negative marginal effect, (ii) $4.6(0.023 / 0.005)$ for a negative marginal effect and (iii) 7.13 $(0.164 / 0.023)$ for a positive marginal effect. It follows that relatively higher levels of bilateral aid are needed to reverse the adverse effect of unclear terrorism on economic growth, as opposed to the quantity needed to reverse the positive impact of domestic and total terrorisms on growth. 
Fourth, one net positive effect and two negative net negative effects are apparent. Accordingly, the net effect of bilateral aid on the effect of domestic terrorism on growth is 0.0015 in the median while the corresponding net effects with unclear terrorism and total terrorism are -0.0448 and -0.0029 in that order. For example, in the fifth column of Panel A in Table 4, the net effect on GDP growth from the interaction between domestic terrorism and bilateral aid is $0.0015([-0.005 \times 5.181]+0.0274)$. Where, the mean value of bilateral aid is 5.181, the unconditional impact of domestic terrorism is 0.0274 while the conditional impact from the interaction between domestic terrorism and bilateral aid is -0.005 .

The statistical significant control variables have the expected signs for the most part. (1) Trade has a positive effect, with some evidence of increasing threshold in the RHS of Panel A. (2) Infrastructure has a positive effect on growth with a: (i) positive threshold effect in the RHS of Panel A and (ii) U-shape in Panel B. (3) As expected the exchange rate and political globalisation have positive effects while inflation has a negative impact. (4) The unexpected positive effect of internal/civil conflicts is consistent with the impact of terrorism on growth.

\section{"Insert Table 4 here"}

Four key findings can be confirmed from Table 5 on the relationships among GDP growth, multilateral aid and terrorism dynamics. First, but for the positive effect of transnational terrorism on the RHS of Panel A (in the $10^{\text {th }}$ and $90^{\text {th }}$ quantiles), other terrorism dynamics have negative effects in bottoms quantiles of GDP growth distributions. Second, the effect of foreign aid is consistently positive with a Kuznets shape: increasing from the $10^{\text {th }}$ to the $25^{\text {th }}$ quantiles, and then consistently decreasing to the $75^{\text {th }}$ quantile.

Third, contrary to the intuition motivating our study, the interaction between foreign aid and terrorism does not exclusively increase economic growth as expected. As with the outcomes in Table 4 we found that, in quantiles where terrorism is reported to increase (decrease) economic growth, its interaction with foreign aid decreases (increases) economic growth. Hence; (i) on the RHS of Panel A for 'transnational terrorism and multilateral aid', results at the $10^{\text {th }}$ quantile are contradict our proposition while (ii) on the LHS for 'domestic terrorism and multilateral aid' of the $10^{\text {th }}$ quantile are consistent with our original perception. Moreover, in Panel B the findings are also in accordance with intuition, notably in: (iii) interactions at the median point on the LHS of the panel for 'unclear terrorism and 
multilateral aid' are in accordance with our expectations and with the estimates at the $10^{\text {th }}$ quantile on the RHS of the panel for 'total terrorism and multilateral aid'. Unfortunately, only two thresholds of the moderating multilateral aid are within the range of ' -1.249 to 7.105 ' provided by the summary statistics for all four cases. They are respectively: (i) 1.95 $(0.135 / 0.069)$ for the negative marginal effect on the RHS of Panel A, (ii) $7.25(0.029 / 0.004)$ for a positive marginal effect on the LHS of Panel A, (iii) $8.00(0.136 / 0.017)$ for a positive marginal effect on the LHS of Panel B and (iv) 7.00 (0.028/0.004) for a positive marginal effect on the RHS of Panel B. Therefore, the modifying threshold of 7.25 and 8.00 for items (ii) and (iii) respectively are above the maximum value of multilateral aid which is 7.105. For the thresholds that fall within range, we notice that, like in Table 4, relatively higher levels (or 7.00) of multilateral aid are needed to reverse the negative effect of total terrorism on growth, as opposed to the quantity needed to counteract the positive impact of transnational terrorisms on economic growth (1.95).

Fourth, three negative net effects on economic growth are apparent, notably: (i) in the $10^{\text {th }}$ deciles for the interaction between domestic terrorism and multilateral aid on the one hand and the interaction between transnational terrorism and multilateral aid on the other and (ii) in the median for the interaction between unclear terrorism and multilateral aid.

\section{"Insert Table 5 here"}

The significant control variables have the expected signs for the most part. (1) Trade has a positive effect at the medians. (2) Infrastructure has a positive effect on growth with a decreasing magnitude from the $25^{\text {th }}$ to the $75^{\text {th }}$ quantiles. (3) Consistent with our expectations, the exchange rate and political globalisation have positive impacts while inflation has a negative effect. (4) In accordance with the explanations provided earlier with regard to the outcomes in Table 4, the positive effect of internal/civil conflicts on economic growth unexpected, but is supported by the argument in the literature on the unpredictable impact of terrorism on growth.

In order to improve the robustness of the empirical exercise, a sensitivity analysis is conducted using lagged independent variables. The results are presented in Table 6 and Table 7 which respectively replicate the regressions in Table 4 and Table 5. The findings from the sensitivity analysis are broadly consistent with the findings of Tables 4-5, with the exception that, no net effects can be computed because in every specification, at least one estimated 
coefficient necessary for the computation of a net effect is not significant. However, in the section that follows, the further discussion of results and policy implications are based on Tables 4-5 because of two main reasons. On the one hand, we are working with three year non-overlapping intervals and hence, lagged values are already integrated in the computation of the averages. On the other hand, net effects are not apparent in the findings of Tables 6-7 and the findings of these tables are broadly consistent with those of Tables 4-5 in terms of unconditional and conditional impacts of foreign aid and terrorism dynamics.

\subsection{Further discussion of results and policy implications}

Whereas we expected foreign aid to consistently promote economic growth, the positive effects of terrorism on economic growth were unexpected. Evidence of the latter was established for two terrorism dynamics (domestic and total) in the regressions on bilateral aid and for the corresponding regressions on multilateral aid. Consistent with Asongu (2015a), a possible explanation for this unexpected result is that the damaging consequences of some of the incidents of terrorism which occurred during the period of study (1984-2008) were effectively neutralised by the sampled countries. It is important to note that, the 2014 Global Terrorism Index (GTI, 2014, p. 13) showed that terrorists' activities have substantially increased in the aftermath of the 2011 Arab Spring. Hence, this unexpected positive impact of terrorism is in accordance with the strand of literature documenting that the damaging consequences of terrorism could effectively be absorbed by those economies which have relatively highly developed infrastructure levels (Gaibulloev \& Sandler, 2009). Nevertheless, it is noteworthy that such positive terrorism-growth outcomes are not supported by the results obtained by Meierrieks and Gries (2013) and Öcal and Yildirim (2010). A likely explanation for this inconsistency is that, whereas the latter is focused on Turkey exclusively, our study distinguishes itself from the former because it embodies both the Cold war and post Cold war eras. Such implies that blanket policy initiatives to boost economic growth by tackling terrorism around the world should be treated with caution, especially in a periodicity prior to the 2011 Arab Spring.

A second bone of contention is the unexpected negative impact of the interaction between development assistance and terrorism on economic growth. A possible explanation to this surprising dynamic could be traced to the political economy of foreign aid. It follows that some types of foreign aid initially destined to promote economic growth by fighting terrorism may run counter to their intended purposes, especially when the underlying effect of terrorism 
on growth are not properly understood by foreign donors. For instance, we found that in situations where these interactions exhibited a negative effect on economic growth, the underlying impact on economic growth of terrorism per se is positive. This finding is consistent with the narrative by Eubank (2012) and Asongu (2015b) that over-reliance on foreign aid could induce more political instability in the beneficiary developing countries. As a policy implication, it is important to understand the initial effect of terrorism on economic growth before deploying foreign aid to mitigating a 'potentially negative' impact of terrorist incidents on economic growth.

The impact of foreign aid on economic growth has shown different tendencies: with bilateral aid displaying a wave-like pattern, while multilateral aid consistently decreases from the $25^{\text {th }}$ to the $75^{\text {th }}$ quantiles after a surge from the $10^{\text {th }}$ quantile to the $25^{\text {th }}$ quantile. It follows that the allocation of bilateral aid may not be contingent on initial economic growth levels as compared to multilateral aid, which decreases with economic development in recipient countries. A possible explanation of this difference is that, bilateral aid has more "political economy' strings attached compared to multilateral aid. Accordingly, it is logical to infer that bilateral aid has more conditions attached because it involves two parties and agreements on the nature of the restrictions could easily be reached. This may not be the case with multilateral aid that involves multiple donors with potentially conflicting interests at play. While recent survey literature has found no reliable evidence on the effectiveness of multilateral aid vis-à-vis bilateral aid in the development outcomes of recipient nations (Biscaye et al., 2015), what is important to note is that our findings are logically consistent with the widely accepted view that the provision of bilateral aid by former colonial powers to their former colonies is primarily to preserve some strategic interests and colonial legacies. Moreover, conflicting strategic interests of multilateral donors may indulge them to allocate aid on development outcomes. This interpretation is in conformity with Asongu (2014c), “Aid is the outcome of bargaining in a kind of political market made up of donor aid bureaucracies, multilateral aid agencies and recipient government officials. Indeed donors pursue multiple goals and these vary over time. For instance, economic gains seem important in Japanese aid, global welfare improvement in Nordic aid and political goals in French aid. Hence, few would object to the inference that our findings may also be explained by a motivation of the French to maintain their colonial legacies and influence in Africa" (p. 472).

Overall, our findings of a positive effect of development assistance on economic growth are at odds with a recent strand of literature which questions the economics of 
development assistance. They include: Marglin (2013), Wamboye et al. (2013), Titumir and Kamal (2013), Banuri (2013), Ghosh (2013), Krause (2013), Monni and Spaventa (2013), Amin (2013), Obeng-Odoom (2013) and Quartey and Afful-Mensah (2014). Conversely, the estimated positive effect: (i) confirms the stream of literature on the clarification of the questionable economics of development assistance (Asongu, 2014d) and (ii) the positive rewards of foreign aid on economic growth (Gyimah-Brempong \& Racine, 2014; Kargbo \& Sen, 2014), especially when channelled via educational mechanisms (Asiedu \& Nandwa, 2007; Asiedu, 2014). Accordingly the second point (ii) is important because, as we have seen above, Asongu and Nwachukwu (2015) concluded that foreign aid improves education and lifelong-learning and in a latter study, they established that education and lifelong-learning decrease political instability and violence (Asongu \& Nwachukwu, 2016b), which are positively associated with terrorist activities.

We now devote some space to discussing how the findings relate to a specific strand of the literature on the use of foreign aid to mitigate the negative effect of terrorism on development outcomes. Bandyopadhyay et al. (2014) and Efobi et al. (2015) used FDI as the development outcome whereas Asongu (2015a) employed the GDP growth rate as in the present study. The fact that the empirical evidence in these three studies is based on the same sample and periodicity facilitates a comparative assessment of the findings in our present line of inquiry. Our findings have only partially confirmed the conclusions of the stream on FDI, which broadly sustains that foreign aid dampens the negative effect of terrorism on FDI. With regard to the study on GDP growth, our results: (i) confirm the position that, the magnitude of the role of foreign aid in stimulating growth is substantially higher than the positive or negative effects of terrorism on growth; (ii) only partially validate the unexpected consequences of the interaction between terrorism and aid in inducing a damaging impact on economic growth; (iii) do not reliably confirm the results that the favourable impact of aid on economic growth is higher in nations with above-median average because, while the patterns are wave-like for bilateral aid across the growth distributions, they consistently display an increasing magnitude from the $25^{\text {th }}$ to the $75^{\text {th }}$ quantiles, with respect to multilateral aid; (iv) partially established the position that the effect of multilateral aid is insignificant in abovemedian GDP growth nations because, we have demonstrated that it is consistently insignificant at the $90^{\text {th }}$ quantile of the growth distributions and (v) partly confirm the position that the effect of unclear terrorism is negative and that above-average multilateral aid can be employed to reverse this destructive effect. We reported that while the growth damaging 
impact of unclear terrorism is persistent across the various quantiles, the threshold of multilateral aid required to reverse this negative impact is outside the range observed for our sample of study. By contrast, the bilateral aid threshold required to reverse the adverse consequences of unclear terrorism is within range. It is important to note that this study steers clear of Asongu (2015a) on methodological and conditional specification grounds. The previous Asongu (2015a) study employed the: (i) Generalised Methods of Moments with forward orthogonal deviations and (ii) GDP growth median as the conditional cut-off for two comparative sub-samples.

\section{Conclusion and further research directions}

In this study, we have investigated the role of development assistance in reducing a hypothetically negative impact of terrorism on economic growth, using a panel of 78 developing nations with data for the period 1984-2008. The empirical evidence is based on interactive Quantile regressions. Domestic, transnational, unclear and total terrorism dynamics are employed while development assistance consists of: bilateral and multilateral aid variables. The following findings are established. First for bilateral aid: (i) the effect on GDP growth of domestic and transnational terrorism is insignificant at the median quantile. Unclear terrorism mitigate economic growth in bottom quantiles of the distribution while total terrorism has a positive effect at the median and (ii) the effect of foreign aid on the economic growth is positive with a wave-like pattern: increasing, decreasing and increasing again from the bottom to the top quantiles of the distributions. Second, with regard to multilateral aid: (i), with the exception of the positive effect of transnational terrorism in the $10^{\text {th }}$ and $90^{\text {th }}$ quantiles, other terrorism dynamics have negative effects in bottoms quantiles of GDP growth distributions and (ii) the effect of foreign aid is persistently positive with a Kuznets shape: increasing from the $10^{\text {th }}$ to the $25^{\text {th }}$ quantile, then consistently decreasing to the $75^{\text {th }}$ quantile. Third, for both types of aid, contrary to the intuition motivating our study, the interaction between foreign aid and terrorism does not reliably increase economic growth as expected.

With regard to the investigated hypothesis, we have consistently established that in quantiles where terrorism is found to increase (decrease) economic growth, its interaction with foreign aid decreases (increases) economic growth. First, the interactions of (i) 'domestic terrorism and bilateral aid', and (ii) 'total terrorism and bilateral aid', at the medians reject the hypothesis, while (iii) the nexus between 'unclear terrorism and bilateral aid', at the $25^{\text {th }}$ quantile confirm the hypothesis. Second, the interactions of: (i) 'transnational 
terrorism and multilateral aid' at the $10^{\text {th }}$ quantile do not validate the hypothesis while (ii) 'domestic terrorism and multilateral aid' at the $10^{\text {th }}$ quantile (iii) 'unclear terrorism and multilateral aid' at the median and (iv) 'total terrorism and multilateral aid' at the $10^{\text {th }}$ quantile certify the hypothesis. Unfortunately, thresholds of the modifying multilateral aid in the second (ii) and third (iii) cases are not within the range observed for our countries during the period of study. Comparing thresholds of the moderating aid variables for which the hypothesis is either rejected or accepted reveals that relatively higher levels of multilateral (bilateral) aid are needed to reverse the negative effect of total (unclear) terrorism on growth, as opposed to the quantity needed to reverse the positive impact of transnational (domestic and total) terrorism(s) on growth.

Whereas some tendencies in (i) the impact of terrorism on growth and (ii) the effect of the 'interaction between aid dynamics and terrorism on economic growth' are contrary to what we expected, we cannot be blamed for carrying out the research since, our intuitions have been sound from a preliminary assessment of the correlation coefficients. Accordingly, the initial correlation coefficients between the independent variables of interest and growth have been consistent with our hypothetical framework, notably: a positive (negative) nexus between GDP growth and foreign aid (terrorism). The partial evidence of the positive effect of terrorism on growth confirms the widely held caution in econometrics, in which correlations should not be extrapolated to causalities.

The scant evidence of positive net effects is consistent with recent terrorism literature on the role of foreign in reducing the effects of terrorism on trade (Asongu \& Kodila-Tedika, 2017b) on the one hand and on the other hand, the mixed impacts of net effects are also in accordance with Asongu and Nwachukwu (2016c). Overall the findings broadly indicate that foreign aid is a necessary but not a sufficient policy tool for completely dampening the effects of terrorism on economic growth.

As we noted in the motivation, data and discussion of results sections, the data used in this study was shared with us by Bandyopadhyay et al. (2014). Hence, we have investigated the problem statement of Bandyopadhyay et al. (2014) within an economic growth context while using an estimation approach that takes initial levels of economic growth into account. Instead of putting the puzzling results in a file drawer and contributing to publication bias in scientific literature, we have offered some explanations to them.

Understanding the channels via which terrorism positively impacts growth is an interesting future line of inquiry. In the same light, future studies could also be positioned on 
clarifying why and how terrorism may interact with foreign aid to exert a negative effect on economic growth. It would also be motivating to position a study on a post-2011 sample to assess how recent terrorism trends documented by the GTI $(2014$, p. 13) play-out in the underlying interconnections. Last but not the least, consistent with the literature review (Asiedu \& Nandwa, 2007; Johnson \& Quartery, 2009; Asiedu, 2014: Asongu, 2014c), it would be worthwhile to examine the role the modifying policy variable by further decomposing aid into more categories. Another future research direction worth pursuing is to investigate whether the established linkages withstand empirical scrutiny when annual data is used while controlling for country heterogeneity. This builds on the caveat that the use of data averages mitigates the effect of some heterogeneity that could influence the findings. It is important to note that this analysis uses panel data based on pooled regression. With data of annual periodicity, country heterogeneity can be better articulated using fixed or random effects regressions.

Table 1: Definitions and sources of variables

\begin{tabular}{|c|c|c|c|}
\hline Variables & Signs & Definitions & Sources \\
\hline GDP growth & GDPg & GDP growth rate (annual \%) & \multirow{13}{*}{$\begin{array}{l}\text { Bandyopadhyay } \\
\text { et al. (2014) }\end{array}$} \\
\hline Trade Openness & LnTrade & Ln. of Exports plus Imports of Commodities (\% of GDP) & \\
\hline Infrastructure & LnTel & Ln. of Number of Telephone lines (per 100 people) & \\
\hline Inflation & LnInflation & Ln. of Consumer Price Index ( $\%$ of annual) & \\
\hline Exchange rate & LnXrate & Ln. of Exchange rate (local currency per USD) & \\
\hline Bilateral Aid & LnBilaid & Ln. of Bilateral aid, net disbursement (million USD) & \\
\hline Multilateral Aid & LnMulaid & Ln. of Multilateral aid, net disbursement (million USD) & \\
\hline Domestic terrorism & Domter & Number of Domestic terrorism incidents & \\
\hline $\begin{array}{l}\text { Transnational } \\
\text { terrorism }\end{array}$ & Tranater & Number of Transnational terrorism incidents & \\
\hline Unclear terrorism & Unclter & Number of terrorism incidents whose category in unclear & \\
\hline Total terrorism & Totter & Total number of terrorism incidents & \\
\hline $\begin{array}{l}\text { Political } \\
\text { globalisation }\end{array}$ & LnPolglob & Ln. of Index of political globalisation & \\
\hline Internal conflicts & Civcon & Index of internal civil conflicts & \\
\hline
\end{tabular}


Table 2: Summary statistics

\begin{tabular}{lccccc}
\hline & Mean & S.D & Minimum & Maximum & Obs \\
\cline { 2 - 6 } GDP growth & 3.852 & 3.467 & -10.933 & 17.339 & 612 \\
Trade Openness (ln) & 4.118 & 0.534 & 2.519 & 5.546 & 612 \\
Infrastructure (ln) & 1.475 & 1.017 & 0.091 & 4.031 & 616 \\
Inflation (ln) & 2.414 & 1.384 & -3.434 & 9.136 & 581 \\
Exchange rate (ln) & 2.908 & 3.870 & -22.121 & 21.529 & 618 \\
Bilateral Aid (ln) & 5.181 & 1.286 & 0.765 & 8.362 & 602 \\
Multilateral Aid (ln) & 4.163 & 1.518 & -1.249 & 7.105 & 600 \\
Domestic terrorism (ln) & 14.292 & 45.179 & 0 & 419.33 & 624 \\
Transnational terrorism (ln) & 2.316 & 6.127 & 0 & 63 & 624 \\
Unclear terrorism(ln) & 1.972 & 7.479 & 0 & 86 & 624 \\
Total terrorism(ln) & 18.581 & 55.595 & 0 & 477.66 & 624 \\
Political globalisation (ln) & 4.036 & 0.301 & 2.861 & 4.530 & 624 \\
Internal conflicts & 0.965 & 1.906 & 0 & 10 & 615
\end{tabular}

S.D: Standard Deviation. Obs: Observations. 
Table 3: Correlation Matrix

\begin{tabular}{|c|c|c|c|c|c|c|c|c|c|c|c|c|c|}
\hline GDPg & LnTrade & LnTel & LnInflation & LnXrate & LnBilad & LnMulaid & Domter & Tranater & Unclter & Totter & LnPolglob & Civcon & \\
\hline \multirow[t]{13}{*}{1.000} & 0.089 & 0.065 & -0.236 & 0.112 & 0.195 & 0.178 & -0.058 & -0.021 & -0.042 & -0.055 & 0.117 & -0.010 & GDPg \\
\hline & 1.000 & 0.296 & -0.230 & 0.043 & -0.267 & -0.289 & -0.236 & -0.206 & -0.240 & -0.246 & -0.122 & -0.299 & LnTrade \\
\hline & & 1.000 & -0.121 & -0.191 & -0.376 & -0.514 & 0.023 & 0.072 & -0.003 & 0.026 & 0.268 & -0.183 & LnTel \\
\hline & & & 1.000 & -0.284 & -0.047 & -0.023 & 0.171 & 0.164 & 0.091 & 0.169 & -0.150 & 0.185 & LnInflation \\
\hline & & & & 1.000 & 0.114 & 0.183 & -0.081 & -0.001 & -0.050 & -0.073 & 0.089 & -0.120 & LnXrate \\
\hline & & & & & 1.000 & 0.721 & 0.116 & 0.088 & 0.093 & 0.117 & 0.233 & 0.259 & LnBilaid \\
\hline & & & & & & 1.000 & 0.014 & -0.039 & 0.069 & 0.016 & 0.167 & 0.194 & LnMulaid \\
\hline & & & & & & & 1.000 & 0.743 & 0.733 & 0.993 & 0.127 & 0.428 & Domter \\
\hline & & & & & & & & 1.000 & 0.528 & 0.785 & 0.120 & 0.418 & Tranater \\
\hline & & & & & & & & & 1.000 & 0.789 & 0.072 & 0.347 & Unclter \\
\hline & & & & & & & & & & 1.000 & 0.126 & 0.441 & Totter \\
\hline & & & & & & & & & & & 1.000 & -0.024 & LnPolglob \\
\hline & & & & & & & & & & & & 1.000 & Civcon \\
\hline
\end{tabular}

GDPg: GDP growth rate. LnTrade: Trade Openness. LnTel: Number of Telephone lines. LnXrate: Exchange rate. LnBilaid: Bilateral aid. LnMulaid: Multilater aid. Domter: Number of Domestic terrorism incidents. Tranater: Number of Transnational terrorism incidents. Unclter: Number of terrorism incidents whose category in unclear. Totter: Total number of terrorism incidents. LnPolglob: Index of political globalisation. Civcon: Index of internal civil conflicts. 
Table 4: GDPg, Bilateral aid, Terrorism

Dependent Variable: GDP growth

Panel A: Domestic Terrorism and Transnational Terrorism

Domestic Terrorism (Domter)

Transnational Terrorism (Tranater)

\begin{tabular}{|c|c|c|c|c|c|c|c|c|c|c|c|c|}
\hline Constant & $\begin{array}{l}-2.393 \\
(0.416)\end{array}$ & $\begin{array}{l}-12.84 * * \\
(0.014)\end{array}$ & $\begin{array}{l}-6.043 * * \\
(0.031)\end{array}$ & $\begin{array}{l}-4.433 * \\
(0.053)\end{array}$ & $\begin{array}{l}-0.522 \\
(0.902)\end{array}$ & $\begin{array}{l}3.051 \\
(0.527)\end{array}$ & $\begin{array}{l}-12.0 * * * \\
(0.000)\end{array}$ & $\begin{array}{l}-4.07 * * * \\
(0.000)\end{array}$ & $\begin{array}{l}-6.58 * * * \\
(0.000)\end{array}$ & $\begin{array}{l}-6.35 * * * \\
(0.000)\end{array}$ & $\begin{array}{l}-11.36 * * * * \\
(0.001)\end{array}$ & $\begin{array}{l}-17.2 * * * \\
(0.004)\end{array}$ \\
\hline Domter & $\begin{array}{l}0.018 \\
(0.153)\end{array}$ & $\begin{array}{l}0.0003 \\
(0.978)\end{array}$ & $\begin{array}{l}0.009 \\
(0.442)\end{array}$ & $\begin{array}{l}0.0274 * * \\
(0.037)\end{array}$ & $\begin{array}{l}0.022 \\
(0.253)\end{array}$ & $\begin{array}{l}0.001 \\
(0.953)\end{array}$ & --- & --- & --- & --- & --- & --- \\
\hline Tranater & --- & --- & --- & --- & --- & --- & $\begin{array}{l}0.030 \\
(0.614)\end{array}$ & $\begin{array}{l}-0.001 \\
(0.942)\end{array}$ & $\begin{array}{l}-0.002 \\
(0.935)\end{array}$ & $\begin{array}{l}0.006 \\
(0.910)\end{array}$ & $\begin{array}{l}0.013 \\
(0.924)\end{array}$ & $\begin{array}{l}0.066 \\
(0.591)\end{array}$ \\
\hline LnBilaid & $\begin{array}{l}0.698 * * * \\
(0.000)\end{array}$ & $\begin{array}{l}0.746 * * * \\
(0.004)\end{array}$ & $\begin{array}{l}0.91 * * * \\
(0.000)\end{array}$ & $\begin{array}{l}\mathbf{0 . 8 2 3} * * * \\
(\mathbf{0 . 0 0 0 )}\end{array}$ & $\begin{array}{l}\text { 0.581** } \\
(\mathbf{0 . 0 2 0})\end{array}$ & $\begin{array}{l}0.751^{* * *} \\
(0.012)\end{array}$ & $\begin{array}{l}0.209 * \\
(0.086)\end{array}$ & $\begin{array}{l}0.117 * * \\
(0.022)\end{array}$ & $\begin{array}{l}0.150 * * * \\
(0.001)\end{array}$ & $\begin{array}{l}0.150 * * \\
(0.038)\end{array}$ & $\begin{array}{l}0.325^{*} \\
(0.064)\end{array}$ & $\begin{array}{l}0.250 \\
(0.398)\end{array}$ \\
\hline Domter $\times$ LnBilaid & $\begin{array}{l}-0.004 * \\
(0.075)\end{array}$ & $\begin{array}{l}-0.002 \\
(0.462)\end{array}$ & $\begin{array}{l}-0.003 \\
(0.138)\end{array}$ & $\begin{array}{l}-0.005 * * \\
(0.016)\end{array}$ & $\begin{array}{l}-0.005 \\
(0.156)\end{array}$ & $\begin{array}{l}-0.0002 \\
(0.965)\end{array}$ & --- & --- & --- & --- & --- & --- \\
\hline Tranater $\times$ LnBilaid & --- & --- & --- & --- & --- & --- & $\begin{array}{l}-0.012 \\
(0.277)\end{array}$ & $\begin{array}{l}-0.002 \\
(0.635)\end{array}$ & $\begin{array}{l}0.001 \\
(0.842)\end{array}$ & $\begin{array}{l}-0.002 \\
(0.820)\end{array}$ & $\begin{array}{l}-0.009 \\
(0.716)\end{array}$ & $\begin{array}{l}-0.024 \\
(0.312)\end{array}$ \\
\hline LnTrade & $\begin{array}{l}0.489 \\
(0.167)\end{array}$ & $\begin{array}{l}0.194 \\
(0.768)\end{array}$ & $\begin{array}{l}0.490 \\
(0.129)\end{array}$ & $\begin{array}{l}0.713 \text { **** } \\
(\mathbf{0 . 0 0 0 )}\end{array}$ & $\begin{array}{l}0.513 \\
(0.289)\end{array}$ & $\begin{array}{l}0.438 \\
(0.434)\end{array}$ & $\begin{array}{l}2.486 * * * \\
(0.000)\end{array}$ & $\begin{array}{l}0.340 * * * \\
(0.001)\end{array}$ & $\begin{array}{l}0.964 * * * \\
(0.000)\end{array}$ & $\begin{array}{l}1.161 * * * \\
(0.000)\end{array}$ & $\begin{array}{l}\text { 2.303*** } \\
(\mathbf{0 . 0 0 0 )}\end{array}$ & $\begin{array}{l}4.065 * * * \\
(0.000)\end{array}$ \\
\hline LnInflation & $\begin{array}{l}-0.293^{*} \\
(0.060)\end{array}$ & $\begin{array}{l}-0.643 * * \\
(0.035)\end{array}$ & $\begin{array}{l}-0.38 * * * \\
(0.008)\end{array}$ & $\begin{array}{l}0.044 \\
(0.640)\end{array}$ & $\begin{array}{l}0.115 \\
(0.497)\end{array}$ & $\begin{array}{l}0.220 \\
(0.247)\end{array}$ & $\begin{array}{l}0.110 \\
(0.317)\end{array}$ & $\begin{array}{l}-0.031 \\
(0.522)\end{array}$ & $\begin{array}{l}-0.015 \\
(0.710)\end{array}$ & $\begin{array}{l}0.021 \\
(0.717)\end{array}$ & $\begin{array}{l}0.094 \\
(0.469)\end{array}$ & $\begin{array}{l}0.131 \\
(0.541)\end{array}$ \\
\hline LnInfrastructure & $\begin{array}{l}0.447 * * \\
(0.011)\end{array}$ & $\begin{array}{l}0.739 * * \\
(0.021)\end{array}$ & $\begin{array}{l}0.487 * * * \\
(0.006)\end{array}$ & $\begin{array}{l}0.347^{* * *} \\
(0.023)\end{array}$ & $\begin{array}{l}0.341 \\
(0.230)\end{array}$ & $\begin{array}{l}0.908 * * * \\
(0.002)\end{array}$ & $\begin{array}{l}0.473 * * * \\
(0.002)\end{array}$ & $\begin{array}{l}0.169 * * \\
(0.010)\end{array}$ & $\begin{array}{l}0.271 * * * \\
(0.000)\end{array}$ & $\begin{array}{l}0.564 * * * \\
(0.000)\end{array}$ & $\begin{array}{l}0.572 \text { *** } \\
(0.009)\end{array}$ & $\begin{array}{l}1.172 * * * * \\
(0.001)\end{array}$ \\
\hline LnXrate (Exchange rate) & $\begin{array}{l}0.053 \\
(0.328)\end{array}$ & $\begin{array}{l}0.073 \\
(0.374)\end{array}$ & $\begin{array}{l}0.033 \\
(0.453)\end{array}$ & $\begin{array}{l}0.048 \\
(0.183)\end{array}$ & $\begin{array}{l}0.038 \\
(0.594)\end{array}$ & $\begin{array}{l}0.056 \\
(0.353)\end{array}$ & $\begin{array}{l}0.066 \text { *** } \\
(0.041)\end{array}$ & $\begin{array}{l}-0.004 \\
(0.811)\end{array}$ & $\begin{array}{l}0.026^{*} \\
(0.073)\end{array}$ & $\begin{array}{l}0.029 \\
(0.182)\end{array}$ & $\begin{array}{l}0.083 * \\
(0.090)\end{array}$ & $\begin{array}{l}0.109 \\
(0.162)\end{array}$ \\
\hline Ln (Political globalisation) & $\begin{array}{l}0.161 \\
(0.782)\end{array}$ & $\begin{array}{l}2.207 * * \\
(0.020)\end{array}$ & $\begin{array}{l}0.411 \\
(0.448)\end{array}$ & $\begin{array}{l}0.102 \\
(0.829)\end{array}$ & $\begin{array}{l}0.044 \\
(0.960)\end{array}$ & $\begin{array}{l}-0.810 \\
(0.421)\end{array}$ & $\begin{array}{l}0.489 \\
(0.282)\end{array}$ & $\begin{array}{l}0.535 * * * \\
(0.000)\end{array}$ & $\begin{array}{l}0.562 * * * \\
(0.003)\end{array}$ & $\begin{array}{l}0.407 \\
(0.152)\end{array}$ & $\begin{array}{l}0.573 \\
(0.384)\end{array}$ & $\begin{array}{l}0.620 \\
(0.548)\end{array}$ \\
\hline Civil Conflicts & $\begin{array}{l}0.077 \\
(0.435)\end{array}$ & $\begin{array}{l}0.121 \\
(0.491)\end{array}$ & $\begin{array}{l}0.189 * * \\
(0.026)\end{array}$ & $\begin{array}{l}0.141 * \\
(0.056)\end{array}$ & $\begin{array}{l}0.103 \\
(0.470)\end{array}$ & $\begin{array}{l}0.002 \\
(0.987)\end{array}$ & $\begin{array}{l}0.139 \\
(0.155)\end{array}$ & $\begin{array}{l}0.051^{*} \\
(0.091)\end{array}$ & $\begin{array}{l}-0.017 \\
(0.526)\end{array}$ & $\begin{array}{l}-0.025 \\
(0.554)\end{array}$ & $\begin{array}{l}0.085 \\
(0.399)\end{array}$ & $\begin{array}{l}0.399 * * \\
(0.030)\end{array}$ \\
\hline Net effect & na & na & na & 0.0015 & na & na & na & na & na & na & na & na \\
\hline $\begin{array}{l}\text { Pseudo } \mathrm{R}^{2} / \mathrm{R}^{2} \\
\text { Fisher }\end{array}$ & $\begin{array}{l}0.093 \\
\mathbf{5 . 3 1} * * *\end{array}$ & 0.112 & 0.077 & 0.055 & 0.027 & 0.046 & $\begin{array}{l}0.093 \\
\mathbf{3 . 3 0}^{* * * *}\end{array}$ & 0.039 & 0.095 & 0.134 & 0.141 & 0.194 \\
\hline Observations & 540 & 540 & 540 & 540 & 540 & 540 & 538 & 538 & 538 & 538 & 538 & 538 \\
\hline
\end{tabular}

Panel B: Unclear Terrorism and Total Terrorism

Unclear Terrorism (Unclter)

Total Terrorism (Totter)

\begin{tabular}{|c|c|c|c|c|c|c|c|c|c|c|c|c|}
\hline Constant & $\begin{array}{l}-1.790 \\
(0.544)\end{array}$ & $\begin{array}{l}-11.34 * * \\
(0.040)\end{array}$ & $\begin{array}{l}-5.894 * * \\
(0.026)\end{array}$ & $\begin{array}{l}-3.497 \\
(0.195)\end{array}$ & $\begin{array}{l}-1.372 \\
(0.748)\end{array}$ & $\begin{array}{l}3.241 \\
(0.490)\end{array}$ & $\begin{array}{l}-2.370 \\
(0.420)\end{array}$ & $\begin{array}{l}-12.77 * * \\
(0.021)\end{array}$ & $\begin{array}{l}-5.85 * * \\
(0.035)\end{array}$ & $\begin{array}{l}-4.306^{*} \\
(0.054)\end{array}$ & $\begin{array}{l}-0.380 \\
(0.932)\end{array}$ & $\begin{array}{l}3.139 \\
(0.501)\end{array}$ \\
\hline Unclter & $\begin{array}{l}0.033 \\
(0.782)\end{array}$ & $\begin{array}{l}-0.178 * \\
(0.082)\end{array}$ & $\begin{array}{l}-0.164 * * \\
(0.025)\end{array}$ & $\begin{array}{l}0.039 \\
(0.736)\end{array}$ & $\begin{array}{l}0.016 \\
(0.954)\end{array}$ & $\begin{array}{l}0.012 \\
(0.961)\end{array}$ & --- & --- & --- & --- & --- & --- \\
\hline Totter & --- & --- & --- & --- & --- & --- & $\begin{array}{l}0.015 \\
(0.150)\end{array}$ & $\begin{array}{l}-0.006 \\
(0.606)\end{array}$ & $\begin{array}{l}0.010 \\
(0.285)\end{array}$ & $\begin{array}{l}0.023 * * \\
(0023)\end{array}$ & $\begin{array}{l}0.017 \\
(0.305)\end{array}$ & $\begin{array}{l}0.001 \\
(0.940)\end{array}$ \\
\hline LnBilaid & $\begin{array}{l}0.664 * * * \\
(0.000)\end{array}$ & $\begin{array}{l}0.650 * * \\
(0.022)\end{array}$ & $\begin{array}{l}0.799 * * * \\
(0.000)\end{array}$ & $\begin{array}{l}0.774 * * * \\
(0.000)\end{array}$ & $\begin{array}{l}0.495 * * \\
(0.042)\end{array}$ & $\begin{array}{l}0.741 * * \\
(0.019)\end{array}$ & $\begin{array}{l}0.700 * * * \\
(\mathbf{0 . 0 0 0})\end{array}$ & $\begin{array}{l}0.763 * * * \\
(0.009)\end{array}$ & $\begin{array}{l}0.915 * * * \\
(0.000)\end{array}$ & $\begin{array}{l}0.830 * * * \\
(0.000)\end{array}$ & $\begin{array}{l}0.568 * * \\
(0.029)\end{array}$ & $\begin{array}{l}0.755 * * \\
(0.015)\end{array}$ \\
\hline Unclter $\times$ LnBilaid & $\begin{array}{l}-0.009 \\
(0.648)\end{array}$ & $\begin{array}{l}0.029 \\
(0.117)\end{array}$ & $\begin{array}{l}0.023 * \\
(0.076)\end{array}$ & $\begin{array}{l}-0.012 \\
(0.522)\end{array}$ & $\begin{array}{l}-0.004 \\
(0.921)\end{array}$ & $\begin{array}{l}-0.002 \\
(0.960)\end{array}$ & --- & --- & --- & --- & --- & --- \\
\hline Totter $\times$ LnBilaid & --- & --- & --- & --- & --- & --- & $\begin{array}{l}-0.003 * \\
(0.076)\end{array}$ & $\begin{array}{l}0.0001 \\
(0.967)\end{array}$ & $\begin{array}{l}-0.002 * \\
(0.090\end{array}$ & $\begin{array}{l}- \\
\mathbf{0 . 0 0 5 * * *} \\
(0.000)\end{array}$ & $\begin{array}{l}-0.003 \\
(0.233)\end{array}$ & $\begin{array}{l}-0.0002 \\
(0.945)\end{array}$ \\
\hline LnTrade & $\begin{array}{l}0.482 \\
(0.175)\end{array}$ & $\begin{array}{l}0.178 \\
(0.785)\end{array}$ & $\begin{array}{l}0.586 * \\
(0.056)\end{array}$ & $\begin{array}{l}0.651 * * \\
(0.031)\end{array}$ & $\begin{array}{l}0.781 \\
(0.110)\end{array}$ & $\begin{array}{l}0.414 \\
(0.433)\end{array}$ & $\begin{array}{l}0.484 \\
(0.173)\end{array}$ & $\begin{array}{l}0.289 \\
(0.671)\end{array}$ & $\begin{array}{l}0.489 \\
(0.123)\end{array}$ & $\begin{array}{l}0.699 * * * \\
(0.005)\end{array}$ & $\begin{array}{l}0.658 \\
(0.196)\end{array}$ & $\begin{array}{l}0.421 \\
(0.414)\end{array}$ \\
\hline LnInflation & $\begin{array}{l}-0.308 * \\
(0.056)\end{array}$ & $\begin{array}{l}-0.619 * \\
(0.071)\end{array}$ & $\begin{array}{l}-0.355 * * \\
(0.011)\end{array}$ & $\begin{array}{l}0.027 \\
(0.821)\end{array}$ & $\begin{array}{l}0.095 \\
(0.570)\end{array}$ & $\begin{array}{l}0.217 \\
(0.172)\end{array}$ & $\begin{array}{l}-0.295 * \\
(0.058)\end{array}$ & $\begin{array}{l}-0.624 * \\
(0.057)\end{array}$ & $\begin{array}{l}-\mathbf{0 . 3 8} * * * \\
(0.007)\end{array}$ & $\begin{array}{l}0.044 \\
(0.635)\end{array}$ & $\begin{array}{l}0.079 \\
(0.656)\end{array}$ & $\begin{array}{l}0.216 \\
(0.165)\end{array}$ \\
\hline LnInfrastructure & $\begin{array}{l}0.430 * * \\
(0.013)\end{array}$ & $\begin{array}{l}0.601 * \\
(0.082)\end{array}$ & $\begin{array}{l}0.501 * * * \\
(0.002)\end{array}$ & $\begin{array}{l}0.392 * * \\
(0.029)\end{array}$ & $\begin{array}{l}0.272 \\
(0.334)\end{array}$ & $\begin{array}{l}0.904 * * * \\
(0.003)\end{array}$ & $\begin{array}{l}0.447 * * \\
(0.010)\end{array}$ & $\begin{array}{l}0.771 * * \\
(0.025)\end{array}$ & $\begin{array}{l}0.493 * * * \\
(0.005)\end{array}$ & $\begin{array}{l}0.352 * * \\
(0.018)\end{array}$ & $\begin{array}{l}0.289 \\
(0.327)\end{array}$ & $\begin{array}{l}0.912 * * * \\
(0.002)\end{array}$ \\
\hline LnXrate (Exchange rate) & $\begin{array}{l}0.056 \\
(0.295)\end{array}$ & $\begin{array}{l}0.040 \\
(0.678)\end{array}$ & $\begin{array}{l}0.038 \\
(0.383)\end{array}$ & $\begin{array}{l}0.055 \\
(0.202)\end{array}$ & $\begin{array}{l}0.061 \\
(0.393)\end{array}$ & $\begin{array}{l}0.046 \\
(0.471)\end{array}$ & $\begin{array}{l}0.053 \\
(0.323)\end{array}$ & $\begin{array}{l}0.074 \\
(0.401)\end{array}$ & $\begin{array}{l}0.035 \\
(0.424)\end{array}$ & $\begin{array}{l}0.047 \\
(0.184)\end{array}$ & $\begin{array}{l}0.044 \\
(0.548)\end{array}$ & $\begin{array}{l}0.050 \\
(0.413)\end{array}$ \\
\hline Ln (Political globalisation) & $\begin{array}{l}0.072 \\
(0.900)\end{array}$ & $\begin{array}{l}2.028 * \\
(0.060)\end{array}$ & $\begin{array}{l}0.401 \\
(0.425)\end{array}$ & $\begin{array}{l}-0.007 \\
(0.989)\end{array}$ & $\begin{array}{l}0.102 \\
(0.906)\end{array}$ & $\begin{array}{l}-0.805 \\
(0.440)\end{array}$ & $\begin{array}{l}0.157 \\
(0.787)\end{array}$ & $\begin{array}{l}2.047 * * \\
(0.048)\end{array}$ & $\begin{array}{l}0.364 \\
(0.499)\end{array}$ & $\begin{array}{l}0.078 \\
(0.866)\end{array}$ & $\begin{array}{l}-0.090 \\
(0.922)\end{array}$ & $\begin{array}{l}-0.813 \\
(0.431)\end{array}$ \\
\hline Civil Conflicts & $\begin{array}{l}0.037 \\
(0.678)\end{array}$ & $\begin{array}{l}-0.165 \\
(0.273)\end{array}$ & $\begin{array}{l}0.093 \\
(0.229)\end{array}$ & $\begin{array}{l}0.060 \\
(0.463)\end{array}$ & $\begin{array}{l}0.068 \\
(0.611)\end{array}$ & $\begin{array}{l}0.002 \\
(0.986)\end{array}$ & $\begin{array}{l}0.079 \\
(0.420)\end{array}$ & $\begin{array}{l}0.011 \\
(0.951)\end{array}$ & $\begin{array}{l}0.192 * * \\
(0.023)\end{array}$ & $\begin{array}{l}0.141 * \\
(0.053)\end{array}$ & $\begin{array}{l}0.089 \\
(0.565)\end{array}$ & $\begin{array}{l}0.007 \\
(0.946)\end{array}$ \\
\hline Net effect & na & na & -0.0448 & na & na & na & na & na & na & -0.0029 & na & na \\
\hline $\begin{array}{l}\text { Pseudo } \mathrm{R}^{2} / \mathrm{R}^{2} \\
\text { Fisher }\end{array}$ & $\begin{array}{l}0.088 \\
\mathbf{5 . 1 6}^{* * * *}\end{array}$ & 0.108 & 0.076 & 0.049 & 0.023 & 0.046 & $\begin{array}{l}0.093 \\
\mathbf{5 . 2 9} * * * *\end{array}$ & 0.112 & 0.077 & 0.055 & 0.027 & 0.046 \\
\hline
\end{tabular}


*******: significance levels of 10\%, 5\% and 1\% respectively. Bilaid: Bilateral aid. GDPg: GDP growth rate. OLS: Ordinary Least Squares. $\mathrm{R}^{2}$ for OLS and Pseudo $\mathrm{R}^{2}$ for quantile regression. Lower quantiles (e.g., Q 0.1) signify nations where GDPg is least. na: not applicable because at least one estimated coefficient needed for the computation of net effects is not significant. The mean value of bilateral aid is 5.181 .

\section{Table 5: GDPg, Multilateral aid, Terrorism}

Dependent Variable: GDPg

Panel A: Domestic Terrorism and Transnational Terrorism

Domestic Terrorism (Domter)

Transnational Terrorism (Tranater)

\begin{tabular}{|c|c|c|c|c|c|c|c|c|c|c|c|c|}
\hline & OLS & Q.10 & Q.25 & Q.50 & Q.75 & Q.90 & OLS & Q.10 & Q.25 & Q.50 & Q.75 & Q.90 \\
\hline Constant & $\begin{array}{l}-2.529 \\
(0.382)\end{array}$ & $\begin{array}{l}-13.74 * * \\
(0.013)\end{array}$ & $\begin{array}{l}-4.121 \\
(0.235)\end{array}$ & $\begin{array}{l}-3.098 \\
(0.206)\end{array}$ & $\begin{array}{l}-1.222 \\
(0.736)\end{array}$ & $\begin{array}{l}2.980 \\
(0.654)\end{array}$ & $\begin{array}{l}-2.410 \\
(0.408)\end{array}$ & $\begin{array}{l}-15.6 * * * \\
(0.001)\end{array}$ & $\begin{array}{l}-3.537 \\
(0.301)\end{array}$ & $\begin{array}{l}-4.232 * \\
(0.072)\end{array}$ & $\begin{array}{l}-1.623 \\
(0.645)\end{array}$ & $\begin{array}{l}3.558 \\
(0.565)\end{array}$ \\
\hline Domter & $\begin{array}{l}0.002 \\
(0.719)\end{array}$ & $\begin{array}{l}- \\
\mathbf{0 . 0 2 9} * * * \\
(\mathbf{0 . 0 0 0 )}\end{array}$ & $-0.013 * *$ & $(0.546)$ & -0.0006 & $\begin{array}{l}0.005 \\
(0.641)\end{array}$ & --- & --- & --- & -- & --- & --- \\
\hline Tranater & --- & --- & --- & --- & --- & --- & $\begin{array}{l}0.044 \\
(0.276)\end{array}$ & $\begin{array}{l}0.135 * * * \\
(0.002)\end{array}$ & $\begin{array}{l}0.023 \\
(0.564)\end{array}$ & $\begin{array}{l}0.032 \\
(0.392)\end{array}$ & $\begin{array}{l}-0.014 \\
(0.800)\end{array}$ & $\begin{array}{l}0.123 * * \\
(0.044)\end{array}$ \\
\hline LnMulaid & $\begin{array}{l}0.631 * * * \\
(0.000)\end{array}$ & $\begin{array}{l}0.711 * * * \\
(0.008)\end{array}$ & $\begin{array}{l}0.794 * * * \\
(0.000)\end{array}$ & $\begin{array}{l}0.658 * * * \\
(0.000)\end{array}$ & $\begin{array}{l}0.419 \text { ** } \\
(0.036)\end{array}$ & $\begin{array}{l}0.397 \\
(0.239)\end{array}$ & $\begin{array}{l}0.649 * * * \\
(0.000)\end{array}$ & $\begin{array}{l}0.750 \text { **** } \\
(\mathbf{0 . 0 0 2})\end{array}$ & $\begin{array}{l}0.829 * * * \\
(0.000)\end{array}$ & $\begin{array}{l}0.684 * * * \\
(0.000)\end{array}$ & $\begin{array}{l}0.421 \text { ** } \\
(0.024)\end{array}$ & $\begin{array}{l}0.451 \\
(0.172)\end{array}$ \\
\hline Domter $\times$ LnMulaid & $\begin{array}{l}-0.002 \\
(0.135)\end{array}$ & $\begin{array}{l}0.004 * * * \\
(0.007)\end{array}$ & $\begin{array}{l}0.0007 \\
(0.651)\end{array}$ & $\begin{array}{l}-0.002 * * \\
(0.046)\end{array}$ & $\begin{array}{l}-0.001 \\
(0.545)\end{array}$ & $\begin{array}{l}-0.001 \\
(0.738)\end{array}$ & -- & --- & --- & --- & --- & -- \\
\hline Tranater $\times$ LnMulaid & --- & --- & --- & --- & --- & --- & $\begin{array}{l}-0.016 * \\
(0.081)\end{array}$ & $\begin{array}{l}- \\
\mathbf{0 . 0 6 9} * * * \\
(0.000)\end{array}$ & $\begin{array}{l}-0.027 * * \\
(0.016)\end{array}$ & $\begin{array}{l}-0.012 \\
(0.263)\end{array}$ & $\begin{array}{c}-0.002 \\
(0.871)\end{array}$ & $\begin{array}{l}-0.028 \\
(0.127)\end{array}$ \\
\hline LnTrade & $\begin{array}{l}0.539 \\
(0.136)\end{array}$ & $\begin{array}{l}0.311 \\
(0.641)\end{array}$ & $\begin{array}{l}0.286 \\
(0.457)\end{array}$ & $\begin{array}{l}0.531 * \\
(0.050)\end{array}$ & $\begin{array}{l}0.511 \\
(0.228)\end{array}$ & $\begin{array}{l}0.713 \\
(0.345)\end{array}$ & $\begin{array}{l}0.594 \\
(0.107)\end{array}$ & $\begin{array}{l}0.177 \\
(0.764)\end{array}$ & $\begin{array}{l}0.324 \\
(0.387)\end{array}$ & $\begin{array}{l}0.773 \text { **** } \\
(0.003)\end{array}$ & $\begin{array}{l}0.605 \\
(0.138)\end{array}$ & $\begin{array}{l}0.749 \\
(0.279)\end{array}$ \\
\hline LnInflation & $\begin{array}{l}-0.332 * * \\
(0.032)\end{array}$ & $\begin{array}{l}-0.641 * * \\
(0.041)\end{array}$ & $\begin{array}{l}-0.400 * * \\
(0.025)\end{array}$ & $\begin{array}{l}-0.066 \\
(0.529)\end{array}$ & $\begin{array}{l}0.136 \\
(0.358)\end{array}$ & $\begin{array}{l}-0.053 \\
(0.821)\end{array}$ & $\begin{array}{l}-0.341 * * \\
(0.030)\end{array}$ & $\begin{array}{l}-0.695 * * \\
(0.016)\end{array}$ & $\begin{array}{l}-0.403 * * \\
(0.020)\end{array}$ & $\begin{array}{l}-0.034 \\
(0.734)\end{array}$ & $\begin{array}{l}0.167 \\
(0.244)\end{array}$ & $\begin{array}{l}-0.062 \\
(0.775)\end{array}$ \\
\hline LnInfrastructure & $\begin{array}{l}0.545 * * * \\
(0.004)\end{array}$ & $\begin{array}{l}0.602 \\
(0.157)\end{array}$ & $\begin{array}{l}0.628 * * \\
(0.013)\end{array}$ & $\begin{array}{l}0.515 * * * \\
(0.004)\end{array}$ & $\begin{array}{l}0.502^{*} \\
(0.058)\end{array}$ & $\begin{array}{l}0.468 \\
(0.307)\end{array}$ & $\begin{array}{l}\mathbf{0 . 5 3 7} * * * \\
(\mathbf{0 . 0 0 3 )}\end{array}$ & $\begin{array}{l}0.734 * * \\
(0.044)\end{array}$ & $\begin{array}{l}\mathbf{0 . 6 8 6} * * * \\
(0.006)\end{array}$ & $\begin{array}{l}0.480 * * * \\
(0.006)\end{array}$ & $\begin{array}{l}0.459 * \\
(0.063)\end{array}$ & $\begin{array}{l}0.506 \\
(0.228)\end{array}$ \\
\hline LnXrate (Exchange rate) & $\begin{array}{l}0.031 \\
(0.590)\end{array}$ & $\begin{array}{l}-0.058 \\
(0.545)\end{array}$ & $\begin{array}{l}0.075 \\
(0.147)\end{array}$ & $\begin{array}{l}0.028 \\
(0.473)\end{array}$ & $\begin{array}{l}0.059 \\
(0.356)\end{array}$ & $\begin{array}{l}0.021 \\
(0.836)\end{array}$ & $\begin{array}{l}0.031 \\
(0.576)\end{array}$ & $\begin{array}{l}-0.016 \\
(0.849\end{array}$ & $\begin{array}{l}0.090 * \\
(0.082)\end{array}$ & $\begin{array}{l}0.041 \\
(0.291)\end{array}$ & $\begin{array}{l}0.062 \\
(0.312)\end{array}$ & $\begin{array}{l}0.032 \\
(0.748)\end{array}$ \\
\hline Ln (Political globalisation) & $\begin{array}{l}0.377 \\
(0.527)\end{array}$ & $\begin{array}{l}2.644 * * \\
(0.019)\end{array}$ & $\begin{array}{l}0.434 \\
(0.533)\end{array}$ & $\begin{array}{l}0.342 \\
(0.505)\end{array}$ & $\begin{array}{l}0.423 \\
(0.569)\end{array}$ & $\begin{array}{l}-0.169 \\
(0.912)\end{array}$ & $\begin{array}{l}0.280 \\
(0.649)\end{array}$ & $\begin{array}{l}\text { 3.13*** } \\
(\mathbf{0 . 0 0 2 )}\end{array}$ & $\begin{array}{l}0.197 \\
(0.775)\end{array}$ & $\begin{array}{l}0.312 \\
(0.527)\end{array}$ & $\begin{array}{l}0.416 \\
(0.557)\end{array}$ & $\begin{array}{l}-0.426 \\
(0.764)\end{array}$ \\
\hline Civil Conflicts & $\begin{array}{l}0.121 \\
(0.206)\end{array}$ & $\begin{array}{l}0.047 \\
(0.750)\end{array}$ & $\begin{array}{l}0.193 * \\
(0.078)\end{array}$ & $\begin{array}{l}0.245 * * * \\
(0.002)\end{array}$ & $\begin{array}{l}0.150 \\
(0.228)\end{array}$ & $\begin{array}{l}0.096 \\
(0.675)\end{array}$ & $\begin{array}{l}0.081 \\
(0.332)\end{array}$ & $\begin{array}{l}0.240 * \\
(0.051)\end{array}$ & $\begin{array}{l}0.194 * \\
(0.059)\end{array}$ & $\begin{array}{l}0.170 * * \\
(0.027)\end{array}$ & $\begin{array}{l}0.121 \\
(0.318)\end{array}$ & $\begin{array}{l}0.104 \\
(0.513)\end{array}$ \\
\hline Net effect & na & -0.0123 & na & na & na & na & na & -0.1522 & na & na & na & na \\
\hline Pseudo R²/R & $\begin{array}{l}0.097 \\
\mathbf{5 0 4 * * *}\end{array}$ & 0.125 & 0.089 & 0.056 & 0.031 & 0.021 & $\begin{array}{l}0.094 \\
\mathbf{5 0 4} * * *\end{array}$ & 0.125 & 0.089 & 0.054 & 0.029 & 0.025 \\
\hline $\begin{array}{l}\text { Fisher } \\
\text { Observations }\end{array}$ & $\begin{array}{l}\mathbf{5 . 9 4} * * * \\
536\end{array}$ & 536 & 536 & 536 & 536 & 536 & $\begin{array}{l}\mathbf{5 . 9 4} * * * \\
536\end{array}$ & 536 & 536 & 536 & 536 & 536 \\
\hline
\end{tabular}

Panel B: Unclear Terrorism and Total Terrorism

Unclear Terrorism (Unclter)

Total Terrorism (Totter)

\begin{tabular}{|c|c|c|c|c|c|c|c|c|c|c|c|c|}
\hline & OLS & Q.10 & Q.25 & Q.50 & Q.75 & Q.90 & OLS & Q.10 & Q.25 & Q.50 & Q.75 & Q.90 \\
\hline Constant & $\begin{array}{l}-1.865 \\
(0.521)\end{array}$ & $\begin{array}{l}-12.92 * * \\
(0.024)\end{array}$ & $\begin{array}{l}-2.059 \\
(0.510)\end{array}$ & $\begin{array}{l}-2.835 \\
(0.292)\end{array}$ & $\begin{array}{l}-1.139 \\
(0.748)\end{array}$ & $\begin{array}{l}2.799 \\
(0.645)\end{array}$ & $\begin{array}{l}-2.446 \\
(0.397)\end{array}$ & $\begin{array}{l}-13.4 * * * \\
(0.009)\end{array}$ & $\begin{array}{l}-4.206 \\
(0.251)\end{array}$ & $\begin{array}{l}-3.482 \\
(0.166)\end{array}$ & $\begin{array}{l}-1.499 \\
(0.661)\end{array}$ & $\begin{array}{l}2.981 \\
(0.656)\end{array}$ \\
\hline Unclter & $\begin{array}{l}-0.046 \\
(0.485)\end{array}$ & $\begin{array}{l}-0.018 \\
(0.808)\end{array}$ & $\begin{array}{l}-0.111 * * \\
(0.034)\end{array}$ & $\begin{array}{l}-0.136 * * \\
(0.014)\end{array}$ & $\begin{array}{l}-0.048 \\
(0.518)\end{array}$ & $\begin{array}{l}0.031 \\
(0.598)\end{array}$ & --- & --- & --- & --- & --- & --- \\
\hline Totter & --- & --- & --- & --- & --- & --- & $\begin{array}{l}0.001 \\
(0.776)\end{array}$ & $\begin{array}{l}- \\
\mathbf{0 . 0 2 8} * * * \\
(0.000)\end{array}$ & $-0.009 *$ & 0.003 & -0.0008 & 0.004 \\
\hline LnMulaid & $\begin{array}{l}0.597 * * * \\
(0.000)\end{array}$ & $\begin{array}{l}\text { 0.701**** } \\
(0.009)\end{array}$ & $\begin{array}{l}0.798 * * * \\
(0.000)\end{array}$ & $\begin{array}{l}0.610 * * * \\
(0.000)\end{array}$ & $\begin{array}{l}0.412 * * \\
(0.030)\end{array}$ & $\begin{array}{l}0.391 \\
(0.207)\end{array}$ & $\begin{array}{l}0.631 * * * \\
(0.000)\end{array}$ & $\begin{array}{l}0.685 * * * \\
(0.006)\end{array}$ & $\begin{array}{l}0.788 * * * \\
(0.000)\end{array}$ & $\begin{array}{l}0.665^{* * * *} \\
(0.000)\end{array}$ & $\begin{array}{l}0.414 * * \\
(0.024)\end{array}$ & $\begin{array}{l}0.397 \\
(0.244)\end{array}$ \\
\hline Unclter $\times$ LnMulaid & $\begin{array}{l}0.003 \\
(0.708)\end{array}$ & $\begin{array}{l}0.003 \\
(0.767)\end{array}$ & $\begin{array}{l}0.013 \\
(0.112)\end{array}$ & $\begin{array}{l}0.017^{*} \\
(0.095)\end{array}$ & $\begin{array}{l}0.004 \\
(0.755)\end{array}$ & $\begin{array}{l}-0.005 \\
(0.595)\end{array}$ & --- & --- & --- & --- & --- & --- \\
\hline Totter $\times$ LnMulaid & --- & --- & --- & --- & --- & --- & $\begin{array}{l}-0.001 \\
(0.150)\end{array}$ & $\begin{array}{l}0.004 * * * \\
(0.001)\end{array}$ & $\begin{array}{l}0.0001 \\
(0.911)\end{array}$ & $\begin{array}{l}-0.001 \\
(0.175)\end{array}$ & $\begin{array}{l}-0.001 \\
(0.618)\end{array}$ & $\begin{array}{l}-0.0009 \\
(0.705)\end{array}$ \\
\hline LnTrade & $\begin{array}{l}0.519 \\
(0.154)\end{array}$ & $\begin{array}{l}0.203 \\
(0.770)\end{array}$ & $\begin{array}{l}0.169 \\
(0.682)\end{array}$ & $\begin{array}{l}0.514 * \\
(0.084)\end{array}$ & $\begin{array}{l}0.565 \\
(0.179)\end{array}$ & $\begin{array}{l}0.777 \\
(0.278)\end{array}$ & $\begin{array}{l}0.533 \\
(0.143)\end{array}$ & $\begin{array}{l}0.247 \\
(0.692)\end{array}$ & $\begin{array}{l}0.266 \\
(0.512)\end{array}$ & $\begin{array}{l}\mathbf{0 . 5 8 9} * * \\
(\mathbf{0 . 0 3 5})\end{array}$ & $\begin{array}{l}0.560 \\
(0.159)\end{array}$ & $\begin{array}{l}0.706 \\
(0.355)\end{array}$ \\
\hline LnInflation & $\begin{array}{l}-0.334 * * \\
(0.034)\end{array}$ & $\begin{array}{l}-\mathbf{0 . 7 0 7} * * \\
(\mathbf{0 . 0 3 8})\end{array}$ & $\begin{array}{l}-0.41 * * * \\
(0.000)\end{array}$ & $\begin{array}{l}-0.059 \\
(0.606)\end{array}$ & $\begin{array}{l}0.188 \\
(0.189)\end{array}$ & $\begin{array}{l}-0.052 \\
(0.810)\end{array}$ & $\begin{array}{l}-\mathbf{0 . 3 3 2} * * \\
(\mathbf{0 . 0 3 3})\end{array}$ & $\begin{array}{l}-0.653 \\
(0.026)\end{array}$ & $\begin{array}{l}-0.406 * * \\
(0.027)\end{array}$ & $\begin{array}{l}-0.068 \\
(0.524)\end{array}$ & $\begin{array}{l}0.170 \\
(0.223)\end{array}$ & $\begin{array}{l}-0.052 \\
(0.826)\end{array}$ \\
\hline LnInfrastructure & $\begin{array}{l}0.541 * * * \\
(0.004)\end{array}$ & $\begin{array}{l}0.741 * \\
(0.082)\end{array}$ & $\begin{array}{l}0.694 * * * \\
(0.002)\end{array}$ & $\begin{array}{l}0.577 * * * \\
(0.003)\end{array}$ & $\begin{array}{l}0.478 * \\
(0.066)\end{array}$ & $\begin{array}{l}0.455 \\
(0.286)\end{array}$ & $\begin{array}{l}0.547 * * * \\
(0.004)\end{array}$ & $\begin{array}{l}0.589 \\
(0.139)\end{array}$ & $\begin{array}{l}0.664 * * \\
(0.013)\end{array}$ & $\begin{array}{l}0.509 * * * \\
(0.005)\end{array}$ & $\begin{array}{l}0.474 * \\
(0.051)\end{array}$ & $\begin{array}{l}0.470 \\
(0.310)\end{array}$ \\
\hline LnXrate (Exchange rate) & 0.035 & -0.050 & 0.075 & 0.034 & 0.060 & 0.027 & 0.032 & -0.086 & 0.082 & 0.032 & 0.065 & 0.021 \\
\hline
\end{tabular}




\begin{tabular}{|c|c|c|c|c|c|c|c|c|c|c|c|c|}
\hline & $(0.451)$ & $(0.616)$ & $(0.107)$ & $(0.435)$ & $(0.330)$ & $(0.776)$ & $(0.579)$ & $(0.339)$ & $(0.135)$ & $(0.437)$ & $(0.271)$ & $(0.839)$ \\
\hline Ln (Political globalisation) & $\begin{array}{l}0.269 \\
(0.645)\end{array}$ & $\begin{array}{l}2.488 * * \\
(0.026)\end{array}$ & $\begin{array}{l}0.042 \\
(0.946)\end{array}$ & $\begin{array}{l}0.312 \\
(0.578)\end{array}$ & $\begin{array}{l}0.328 \\
(0.648)\end{array}$ & $\begin{array}{l}-0.170 \\
(0.902)\end{array}$ & $\begin{array}{l}0.363 \\
(0.542)\end{array}$ & $\begin{array}{l}2.678 * * \\
(0.011)\end{array}$ & $\begin{array}{l}0.462 \\
(0.531)\end{array}$ & $\begin{array}{l}0.365 \\
(0.487)\end{array}$ & $\begin{array}{l}0.434 \\
(0.530)\end{array}$ & $\begin{array}{l}-0.165 \\
(0.915)\end{array}$ \\
\hline Civil Conflicts & $\begin{array}{l}0.087 \\
(0.316)\end{array}$ & $\begin{array}{l}0.079 \\
(0.619)\end{array}$ & $\begin{array}{l}0.049 \\
(0.601)\end{array}$ & $\begin{array}{l}0.211 * * \\
(0.010)\end{array}$ & $\begin{array}{l}0.102 \\
(0.365)\end{array}$ & $\begin{array}{l}0.083 \\
(0.650)\end{array}$ & $\begin{array}{l}0.119 \\
(0.208)\end{array}$ & $\begin{array}{l}0.038 \\
(0.795)\end{array}$ & $\begin{array}{l}0.235 * * \\
(0.042)\end{array}$ & $\begin{array}{l}0.155^{*} \\
(0.052)\end{array}$ & $\begin{array}{l}0.120 \\
(0.305)\end{array}$ & $\begin{array}{l}0.096 \\
(0.678)\end{array}$ \\
\hline Net effect & na & na & na & -0.0652 & na & na & na & -0.0113 & na & na & na & na \\
\hline $\begin{array}{l}\text { Pseudo } R^{2} / R^{2} \\
\text { Fisher }\end{array}$ & $\begin{array}{l}0.095 \\
\mathbf{5 . 8 7} * * *\end{array}$ & 0.122 & 0.092 & 0.056 & 0.032 & 0.0215 & $\begin{array}{l}0.096 \\
\mathbf{5 . 9 3}^{* * * *}\end{array}$ & 0.124 & 0.090 & 0.056 & 0.031 & 0.022 \\
\hline Observations & 536 & 536 & 536 & 536 & 536 & 536 & 536 & 536 & 536 & 536 & 536 & 536 \\
\hline
\end{tabular}

***,***: significance levels of $10 \%, 5 \%$ and $1 \%$ respectively. Mulaid: Multilateral aid. GDPg: GDP growth rate. OLS: Ordinary Least Squares. $\mathrm{R}^{2}$ for OLS and Pseudo $\mathrm{R}^{2}$ for quantile regression. Lower quantiles (e.g., Q 0.1) signify nations where GDPg is least. na: not applicable because at least one estimated coefficient needed for the computation of net effects is not significant. The mean value of multilateral aid is 4.163 .

\section{Table 6: GDPg, Bilateral aid, Terrorism (Sensitivity analysis)}

Dependent Variable: GDP growth

Panel A: Domestic Terrorism and Transnational Terrorism

\begin{tabular}{|c|c|c|c|c|c|c|c|c|c|c|c|c|}
\hline & \multicolumn{6}{|c|}{ Domestic Terrorism (Domter) } & \multicolumn{6}{|c|}{ Transnational Terrorism (Tranater) } \\
\hline & OLS & Q.10 & Q.25 & Q.50 & Q.75 & Q.90 & OLS & Q.10 & Q.25 & Q.50 & Q.75 & Q.90 \\
\hline \multirow[t]{2}{*}{ Constant } & -1.882 & - & $-6.664 *$ & -2.281 & 4.445 & 8.004* & - & $-3.043^{* *}$ & - & - & $-9.139 * *$ & -10.760 \\
\hline & $(0.507)$ & $\begin{array}{l}\text { 13.433** } \\
(0.037)\end{array}$ & $(0.093)$ & $(0.370)$ & $(0.226)$ & $(0.092)$ & $\begin{array}{l}9.263 * * * \\
(0.001)\end{array}$ & $(0.025)$ & $\begin{array}{l}4.989 * * * \\
(0.000)\end{array}$ & $\begin{array}{l}6.235 * * * \\
(0.000)\end{array}$ & $(0.016)$ & $(0.118)$ \\
\hline Domter & $\begin{array}{l}0.005 \\
(0.747)\end{array}$ & $\begin{array}{l}-0.007 \\
(0.849)\end{array}$ & $\begin{array}{l}-0.028 \\
(0.219)\end{array}$ & $\begin{array}{l}-0.001 \\
(0.920)\end{array}$ & $\begin{array}{l}0.024 \\
(0.249)\end{array}$ & $\begin{array}{l}\text { à.008 } \\
(0.767)\end{array}$ & --- & --- & --- & --- & -- & --- \\
\hline Tranater & --- & --- & --- & --- & --- & --- & $\begin{array}{l}0.060 \\
(0.304)\end{array}$ & $\begin{array}{l}0.011 \\
(0.848)\end{array}$ & $\begin{array}{l}0.037 \\
(.0523)\end{array}$ & $\begin{array}{l}0.029 \\
(0.691)\end{array}$ & $\begin{array}{l}0.038 \\
(0.818)\end{array}$ & $\begin{array}{l}0.038 \\
(0.898)\end{array}$ \\
\hline LnBilaid & $\begin{array}{l}0.657 * * * \\
(0.000)\end{array}$ & $\begin{array}{l}0.946 \\
(0.005)\end{array}$ & $\begin{array}{l}0.656 * * * \\
(0.002)\end{array}$ & $\begin{array}{l}0.525 * * * \\
(0.000)\end{array}$ & $\begin{array}{l}0.485 * * \\
(0.012)\end{array}$ & $\begin{array}{l}0.726 * * * \\
(0.004)\end{array}$ & $\begin{array}{l}0.151 \\
(0.236)\end{array}$ & $\begin{array}{l}0.083 \\
(0.244)\end{array}$ & $\begin{array}{l}0.092 \\
(0.196)\end{array}$ & $\begin{array}{l}0.163 * \\
(0.073)\end{array}$ & $\begin{array}{l}0.182 \\
(0.364)\end{array}$ & $\begin{array}{l}0.328 \\
(0.369)\end{array}$ \\
\hline Domter $\times$ LnBilaid & $\begin{array}{l}-0.002 \\
(0.510)\end{array}$ & $\begin{array}{l}-0.0002 \\
(0.969)\end{array}$ & $\begin{array}{l}0.004 \\
(0.307)\end{array}$ & $\begin{array}{l}-0.0009 \\
(0.728)\end{array}$ & $\begin{array}{l}-0.005 \\
(0.163)\end{array}$ & $\begin{array}{l}-0.001 \\
(0.729)\end{array}$ & -- & --- & --- & --- & --- & --- \\
\hline Tranater $\times$ LnBilaid & -- & --- & --- & -- & -- & --- & $\begin{array}{l}-0.017 \\
(0.131)\end{array}$ & $\begin{array}{l}-0.004 \\
(0.700)\end{array}$ & $\begin{array}{l}-0.005 \\
(0.587)\end{array}$ & $\begin{array}{l}-0.006 \\
(0.647)\end{array}$ & $\begin{array}{l}-0.011 \\
(0.701)\end{array}$ & $\begin{array}{l}-0.019 \\
(0.728)\end{array}$ \\
\hline Control Variables & Yes & Yes & Yes & Yes & Yes & Yes & Yes & Yes & Yes & Yes & Yes & Yes \\
\hline Net Effects & na & na & na & na & na & na & na & na & na & na & na & na \\
\hline Pseudo $\mathrm{R}^{2} / \mathrm{R}^{2}$ & 0.096 & 0.112 & 0.060 & 0.042 & 0.032 & 0.056 & 0.194 & 0.031 & 0.082 & 0.129 & 0.135 & 0.186 \\
\hline Fisher & $4.63 * * *$ & & & & & & $10.22 * * *$ & & & & & \\
\hline Observations & 473 & 473 & 473 & 473 & 473 & 473 & 472 & 472 & 472 & 472 & 472 & 472 \\
\hline
\end{tabular}

Panel B: Unclear Terrorism and Total Terrorism

\begin{tabular}{|c|c|c|c|c|c|c|c|c|c|c|c|c|}
\hline & \multicolumn{6}{|c|}{ Unclear Terrorism (Unclter) } & \multicolumn{6}{|c|}{ Total Terrorism (Totter) } \\
\hline & OLS & Q.10 & Q.25 & Q.50 & Q.75 & Q.90 & OLS & Q.10 & Q.25 & Q.50 & Q.75 & Q.90 \\
\hline Constant & $\begin{array}{l}-1.264 \\
(0.657)\end{array}$ & $\begin{array}{l}- \\
13.474 * * \\
(0.040)\end{array}$ & $-6.946^{*}$ & -1.907 & $(0.229)$ & $7.935 *$ & -1.891 & $\begin{array}{l}- \\
13.412 * * \\
(0.038)\end{array}$ & $-6.799 *$ & -2.385 & $(0.248)$ & 7.138 \\
\hline Unclter & $\begin{array}{l}0.011 \\
(0.928)\end{array}$ & $\begin{array}{l}-0.287 \\
(0.279)\end{array}$ & $\begin{array}{l}-0.177 \\
(0.259)\end{array}$ & $\begin{array}{l}-0.010 \\
(0924)\end{array}$ & $\begin{array}{l}-0.040 \\
(0.781)\end{array}$ & $\begin{array}{l}0.096 \\
(0.613)\end{array}$ & -- & --- & -- & -- & --- & --- \\
\hline Totter & --- & --- & --- & -- & -- & --- & $\begin{array}{l}0.005 \\
(0.720)\end{array}$ & $\begin{array}{l}0.008 \\
(0.777)\end{array}$ & $\begin{array}{l}-0.010 \\
(0.576)\end{array}$ & $\begin{array}{l}-0.0002 \\
(0.983)\end{array}$ & $\begin{array}{l}0.001 \\
(0.931)\end{array}$ & $\begin{array}{l}0.010 \\
(0.623)\end{array}$ \\
\hline LnBilaid & $\begin{array}{l}0.644 * * * \\
(0.000)\end{array}$ & $\begin{array}{l}0.952 * * * \\
(0.005)\end{array}$ & $\begin{array}{l}0.651 * * * \\
(0.001)\end{array}$ & $\begin{array}{l}0.486 * * * \\
(0.001)\end{array}$ & $\begin{array}{l}0.465 * * \\
(0.013)\end{array}$ & $\begin{array}{l}0.702 * * * \\
(0.004)\end{array}$ & $\begin{array}{l}0.661 * * * * \\
(0.000)\end{array}$ & $\begin{array}{l}0.988 * * * \\
(0.003)\end{array}$ & $\begin{array}{l}0.641 * * * \\
(0.002)\end{array}$ & $\begin{array}{l}0.526 * * * * \\
(0.000)\end{array}$ & $\begin{array}{l}0.480 * * \\
(0.015)\end{array}$ & $\begin{array}{l}0.749 * * * \\
(0.003)\end{array}$ \\
\hline Unclter $\times$ LnBilaid & $\begin{array}{l}-0.010 \\
(0.632)\end{array}$ & $\begin{array}{l}0.048 \\
(0.307)\end{array}$ & $\begin{array}{l}0.023 \\
(0.392)\end{array}$ & $\begin{array}{l}-0.002 \\
(0.903)\end{array}$ & $\begin{array}{l}-0.001 \\
(0.968)\end{array}$ & $\begin{array}{l}-0.025 \\
(0.454)\end{array}$ & -- & --- & --- & --- & --- & --- \\
\hline Totter $\times$ LnBilaid & --- & --- & -- & -- & -- & --- & $\begin{array}{l}-0.001 \\
(0.458)\end{array}$ & $\begin{array}{l}-0.002 \\
(0.615)\end{array}$ & $\begin{array}{l}0.0009 \\
(0.789)\end{array}$ & $\begin{array}{l}-0.001 \\
(0.646)\end{array}$ & $\begin{array}{l}-0.001 \\
(0.603)\end{array}$ & $\begin{array}{l}-0.002 \\
(0.471)\end{array}$ \\
\hline Control Variables & Yes & Yes & Yes & Yes & Yes & Yes & Yes & Yes & Yes & Yes & Yes & Yes \\
\hline Net effects & na & na & na & na & na & na & na & na & na & na & na & na \\
\hline $\begin{array}{l}\text { Pseudo R²/R } \\
\text { Fisher }\end{array}$ & $\begin{array}{l}0.101 \\
\mathbf{5 . 0 1} * * *\end{array}$ & 0.113 & 0.061 & 0.043 & 0.040 & 0.063 & $\begin{array}{l}0.097 \\
\mathbf{4 . 7 3}^{* * *}\end{array}$ & 0.112 & 0.061 & 0.044 & 0.034 & 0.057 \\
\hline Observations & 473 & 473 & 473 & 473 & 473 & 473 & 473 & 473 & 473 & 473 & 473 & 473 \\
\hline
\end{tabular}

*,**,***: significance levels of $10 \%, 5 \%$ and $1 \%$ respectively. Bilaid: Bilateral aid. OLS: Ordinary Least Squares. $\mathrm{R}^{2}$ for OLS and Pseudo $\mathrm{R}^{2}$ for quantile regression. Lower quantiles (e.g., Q 0.1) signify nations where GDPg is least. na: not applicable because at least one estimated coefficient needed for the computation of net effects is not significant. The mean value of bilateral aid is 5.181. 
Table 7: GDPg, Multilateral aid, Terrorism (Sensitivity analysis)

Dependent Variable: GDPg

Panel A: Domestic Terrorism and Transnational Terrorism

\begin{tabular}{|c|c|c|c|c|c|c|c|c|c|c|c|c|}
\hline & \multicolumn{6}{|c|}{ Domestic Terrorism (Domter) } & \multicolumn{6}{|c|}{ Transnational Terrorism (Tranater) } \\
\hline & OLS & Q.10 & Q.25 & Q.50 & Q.75 & Q.90 & OLS & Q.10 & Q.25 & Q.50 & Q.75 & Q.90 \\
\hline Constant & $\begin{array}{l}-1.495 \\
(0.586)\end{array}$ & $\begin{array}{l}-9.697 \\
(0.184)\end{array}$ & $\begin{array}{l}-3.764 \\
(0.335)\end{array}$ & $\begin{array}{l}-2.083 \\
(0.385)\end{array}$ & $\begin{array}{l}2.247 \\
(0.478)\end{array}$ & $\begin{array}{l}8.162 \\
(0.177)\end{array}$ & $\begin{array}{l}-1.456 \\
(0.596)\end{array}$ & $\begin{array}{l}-10.339 \\
(0.142)\end{array}$ & $\begin{array}{l}-5.354 \\
(0.163)\end{array}$ & $\begin{array}{l}-1.560 \\
(0.534)\end{array}$ & $\begin{array}{l}2.463 \\
(0.426)\end{array}$ & $\begin{array}{l}6.806 \\
(0.220)\end{array}$ \\
\hline Domter & $\begin{array}{l}-0.003 \\
(0.657)\end{array}$ & $\begin{array}{l}-0.025 \\
(0.195)\end{array}$ & $\begin{array}{l}0.002 \\
(0.779)\end{array}$ & $\begin{array}{l}-0.001 \\
(0.836)\end{array}$ & $\begin{array}{l}-0.002 \\
(0.812)\end{array}$ & $\begin{array}{l}0.014 \\
(0.379)\end{array}$ & --- & --- & --- & --- & --- & --- \\
\hline Tranater & --- & --- & --- & --- & --- & --- & $\begin{array}{l}0.001 \\
(0.977)\end{array}$ & $\begin{array}{l}-0.087 \\
(0.496)\end{array}$ & $\begin{array}{l}0.058 \\
(0.409)\end{array}$ & $\begin{array}{l}0.007 \\
(0.871)\end{array}$ & $\begin{array}{l}-0.013 \\
(0.807)\end{array}$ & $\begin{array}{l}0.061 \\
(0.544)\end{array}$ \\
\hline LnMulaid & $\begin{array}{l}0.613 * * * \\
(0.000)\end{array}$ & $\begin{array}{l}0.965 * * * \\
(0.008)\end{array}$ & $\begin{array}{l}0.705 * * * \\
(0.000)\end{array}$ & $\begin{array}{l}0.619 * * * \\
(0.000)\end{array}$ & $\begin{array}{l}0.471 * * * \\
(0.003)\end{array}$ & $\begin{array}{l}0.423 \\
(0.160)\end{array}$ & $\begin{array}{l}0.630 * * * \\
(0.000)\end{array}$ & $\begin{array}{l}0.968 * * * \\
(0.007)\end{array}$ & $\begin{array}{l}0.729 * * * \\
(0.000)\end{array}$ & $\begin{array}{l}0.640 * * * \\
(0.000)\end{array}$ & $\begin{array}{l}0.520 * * * \\
(0.001)\end{array}$ & $\begin{array}{l}0.534 * \\
(0.057)\end{array}$ \\
\hline Domter $\times$ LnMulaid & $\begin{array}{l}-0.0006 \\
(0.623)\end{array}$ & $\begin{array}{l}0.003 \\
(0.479)\end{array}$ & $\begin{array}{l}-0.001 \\
(0.553)\end{array}$ & $\begin{array}{l}-0.001 \\
(0.393)\end{array}$ & $\begin{array}{l}-0.0006 \\
(0.778)\end{array}$ & $\begin{array}{l}-0.004 \\
(0.331)\end{array}$ & --- & --- & --- & --- & --- & --- \\
\hline Tranater $\times$ LnMulaid & --- & -- & --- & --- & --- & --- & $\begin{array}{l}-0.008 \\
(0.384)\end{array}$ & $\begin{array}{r}0.005 \\
(0.869)\end{array}$ & $\begin{array}{l}-0.037 * \\
(0.059)\end{array}$ & $\begin{array}{l}-0.018 \\
(0.157)\end{array}$ & $\begin{array}{l}-0.007 \\
(0.622)\end{array}$ & $\begin{array}{l}-0.017 \\
(0.550)\end{array}$ \\
\hline Control Variables & Yes & Yes & Yes & Yes & Yes & Yes & Yes & Yes & Yes & Yes & Yes & Yes \\
\hline Net effects & na & na & na & na & na & na & na & na & na & na & na & na \\
\hline $\begin{array}{l}\text { Pseudo } \mathrm{R}^{2} / \mathrm{R}^{2} \\
\text { Fisher }\end{array}$ & $\begin{array}{l}0.095 \\
\mathbf{4 . 1 7} * * *\end{array}$ & 0.114 & 0.071 & 0.054 & 0.037 & 0.039 & $\begin{array}{l}0.093 \\
\mathbf{4 . 1 8} * * * *\end{array}$ & 0.112 & 0.074 & 0.052 & 0.037 & 0.038 \\
\hline Observations & 465 & 465 & 465 & 465 & 465 & 465 & 465 & 465 & 465 & 465 & 465 & 465 \\
\hline
\end{tabular}

Panel B: Unclear Terrorism and Total Terrorism

\begin{tabular}{|c|c|c|c|c|c|c|c|c|c|c|c|c|}
\hline & \multicolumn{6}{|c|}{ Unclear Terrorism (Unclter) } & \multicolumn{6}{|c|}{ Total Terrorism (Totter) } \\
\hline & OLS & Q.10 & Q.25 & Q.50 & Q.75 & Q.90 & OLS & Q.10 & Q.25 & Q.50 & Q.75 & Q.90 \\
\hline Constant & $\begin{array}{l}-0.752 \\
(0.787)\end{array}$ & $\begin{array}{l}-9.766 \\
(0.135)\end{array}$ & $\begin{array}{l}-3.132 \\
(0.480)\end{array}$ & $\begin{array}{l}-0.809 \\
(0.733)\end{array}$ & $\begin{array}{l}2.926 \\
(0.332)\end{array}$ & $\begin{array}{l}7.535 \\
(0.222)\end{array}$ & $\begin{array}{l}-1.491 \\
(0.587)\end{array}$ & $\begin{array}{l}-9.615 \\
(0.193)\end{array}$ & $\begin{array}{l}-3.802 \\
(0.343)\end{array}$ & $\begin{array}{l}-1.902 \\
(0.420)\end{array}$ & $\begin{array}{l}2.682 \\
(0.417)\end{array}$ & $\begin{array}{l}7.268 \\
(0.213)\end{array}$ \\
\hline Unclter & $\begin{array}{l}-0.107 * \\
(0.076)\end{array}$ & $\begin{array}{l}-0.194 \\
(0.125)\end{array}$ & $\begin{array}{l}-0.060 \\
(0.410)\end{array}$ & $\begin{array}{l}-0.078 * \\
(0.090)\end{array}$ & $\begin{array}{l}-0.072 \\
(0.214)\end{array}$ & $\begin{array}{l}-0.099 \\
(0.405)\end{array}$ & --- & --- & --- & --- & --- & --- \\
\hline Totter & --- & --- & --- & --- & --- & --- & $\begin{array}{l}-0.002 \\
(0.617)\end{array}$ & $\begin{array}{l}-0.023 \\
(0.129)\end{array}$ & $\begin{array}{l}-0.005 \\
(0.494)\end{array}$ & $\begin{array}{l}-0.0008 \\
(0.873)\end{array}$ & $\begin{array}{l}-0.001 \\
(0.829)\end{array}$ & $\begin{array}{l}0.009 \\
(0.441)\end{array}$ \\
\hline LnMulaid & $\begin{array}{l}0.595 * * * \\
(0.000)\end{array}$ & $\begin{array}{l}0.973 \\
(0.002)\end{array}$ & $\begin{array}{l}0.711 * * * \\
(0.000)\end{array}$ & $\begin{array}{l}\mathbf{0 . 6 4 3} * * * \\
(\mathbf{0 . 0 0 0 )}\end{array}$ & $\begin{array}{l}0.466 * * * \\
(0.002)\end{array}$ & $\begin{array}{l}0.316 \\
(0.295)\end{array}$ & $\begin{array}{l}0.617 * * * \\
(0.000)\end{array}$ & $\begin{array}{l}1.005 * * * \\
(0.007)\end{array}$ & $\begin{array}{l}0.705 * * * \\
(0.000)\end{array}$ & $\begin{array}{l}0.645 * * * \\
(0.000)\end{array}$ & $\begin{array}{l}0.484 * * * * \\
(0.000)\end{array}$ & $\begin{array}{l}0.451 \\
(0.122)\end{array}$ \\
\hline Unclter $\times$ LnMulaid & $\begin{array}{l}0.010 \\
(0.270)\end{array}$ & $\begin{array}{l}0.028 \\
(0.231)\end{array}$ & $\begin{array}{l}0.006 \\
(0.665)\end{array}$ & $\begin{array}{l}0.006 \\
(0.454)\end{array}$ & $\begin{array}{l}0.004 \\
(0.711)\end{array}$ & $\begin{array}{l}0.006 \\
(0.777)\end{array}$ & -- & --- & -- & --- & --- & --- \\
\hline Totter $\times$ LnMulaid & --- & --- & --- & --- & --- & --- & $\begin{array}{l}-0.0006 \\
(0.524)\end{array}$ & $\begin{array}{l}0.003 \\
(0.397)\end{array}$ & $\begin{array}{l}-0.0001 \\
(0.954)\end{array}$ & $\begin{array}{l}-0.001 \\
(0.285)\end{array}$ & $\begin{array}{l}-0.001 \\
(0.329)\end{array}$ & $\begin{array}{l}-0.002 \\
(0.361)\end{array}$ \\
\hline Control Variables & Yes & Yes & Yes & Yes & Yes & Yes & Yes & Yes & Yes & Yes & Yes & Yes \\
\hline Net effects & na & na & na & na & na & na & na & na & na & na & na & na \\
\hline Pseudo $\mathrm{R}^{2} / \mathrm{R}^{2}$ & 0.108 & 0.118 & 0.078 & 0.063 & 0.048 & 0.045 & 0.097 & 0.114 & 0.073 & 0.057 & 0.039 & 0.039 \\
\hline Fisher & $5.02 * * *$ & & & & & & $4.15^{* * * *}$ & & & & & \\
\hline Observations & 465 & 465 & 465 & 465 & 465 & 465 & 465 & 465 & 465 & 465 & 465 & 465 \\
\hline
\end{tabular}

***,***: significance levels of $10 \%, 5 \%$ and $1 \%$ respectively. Mulaid: Multilateral aid. OLS: Ordinary Least Squares. $\mathrm{R}^{2}$ for OLS and Pseudo $\mathrm{R}^{2}$ for quantile regression. Lower quantiles (e.g., Q 0.1) signify nations where GDPg is least. na: not applicable because at least one estimated coefficient needed for the computation of net effects is not significant. The mean value of multilateral aid is 4.163 . 


\section{References}

Abadie, A., \& Gardeazabal, J., (2008), "Terrorism and the world economy", European Economic Review, 52(1), pp.1-27.

Akinwale, A. K., (2010). "Integrating the traditional and the modern conflict management strategies in Nigeria", Department of Sociology, Faculty of Social Sciences, University of Ibadan, Nigeria.

Akpan, U. S., Isihak, S. R., \& Asongu, S. A., (2014). "Determinants of Foreign Direct Investment in Fast-Growing Economies: A Study of BRICS and MINT", African Governance and Development Institute Working Paper No. 14/002, Yaoundé.

Alagidede, P., \& Muazu, I., (2017). "On the Causes and Effects of Exchange Rate Volatility on Economic Growth: Evidence from Ghana," Journal of African Business, 18(2), pp. 169193.

Amin, S., (2014). “Aid for Development”, Springer Briefs on Pioneers in Science and Practice, 16, pp. 125-137.

Assefa, T. A., \& Mollick, A. V., (2017). "Financial Development and Economic Growth in Africa," Journal of African Business, 18(3), pp. 320-339.

Asiedu, E. (2014). "Does Foreign Aid in Education Promote Economic Growth? Evidence From Sub-Saharan Africa", Journal of African Development, 16(1), pp. 37-59.

Asiedu, E., \& Nandwa, B., (2007), "On the Impact of Foreign Aid in Education on Growth: How relevant is heterogeneity of aid flows and heterogeneity of aid recipients?", Review of World Economics, 143(4), pp. 631-649.

Asongu, S. A., (2013). "Fighting corruption in Africa: do existing corruption-control levels matter?", International Journal of Development Issues, 12(1), pp. 36-52.

Asongu, S. A., (2014a). "Globalization (fighting), corruption and development: How are these phenomena linearly and nonlinearly related in wealth effects?", Journal of Economic Studies, 3(3), pp. 346-369.

Asongu, S. A., (2014b). "The impact of health worker migration on development dynamics: evidence of wealth effects from Africa", The European Journal of Health Economics, 15(2), pp. 187-201.

Asongu, S. A., (2014c). "The Questionable Economics of Development Assistance in Africa: Hot-Fresh Evidence, 1996-2010", The Review of Black Political Economy, 41(4), pp. 455480.

Asongu, S. A., (2014d). "A Brief Clarification to the Questionable Economics of Foreign Aid for Inclusive Human Development", African Governance and Development Assistance WP 28/14, Yaoundé. 
Asongu, S. A., (2015a). "Foreign Aid, Terrorism and Growth Dynamics in Developing Countries", African Governance and Development Working Paper, Yaoundé.

Asongu, S. A., (2015b). "Drivers of Growth in Fast Emerging Economies: A Dynamic Instrumental Quantile Approach", African Governance and Development Institute Working Paper No. 15/009, Yaoundé.

Asongu, S. A., (2015b). "On Taxation, Political Accountability and Foreign Aid: Empirics to a Celebrated Literature", South African Journal of Economics, 83(2), pp. 180-198.

Asongu, S. A., \& Kodila-Tedika, O., (2017a). "Is Poverty in the African DNA (Gene)?", South African Journal of Economics, 85(4), pp. 533-552.

Asongu, S. A., \& Kodila-Tedika, O., (2016). "Fighting African Conflicts and Crime: Which Governance Tools Matter?", International Journal of Social Economics, 43(5), pp. 466- 485.

Asongu, S. A., \& Kodila-Tedika, O., (2017b). "Trade, Aid and Terror", International Journal of Development Issues, 16(1), pp. 2-24.

Asongu, S. A., \& Nwachukwu, J. C., (2016a). "Revolution empirics: predicting the Arab Spring”, Empirical Economics, 51(2), pp. 439-482.

Asongu, S. A., \& Nwachukwu, J. C., (2015b). "Foreign aid volatility and lifelong learning: demand-side empirics to a textual literature", African Governance and Development Institute Working Paper, No. 15/016.

Asongu, S. A., \& Nwachukwu, J. C., (2016b). "The Role of Lifelong Learning in Political Stability and Non-violence: Evidence from Africa", Journal of Economic Studies, 43(1), pp. 141-164.

Asongu, S. A., \& Nwachukwu, J. C., (2016c). "Conditional linkages between iron ore exports, foreign aid and terrorism”, Mineral Economics, 29(2), pp. 57-70.

Asongu, S. A., \& Nwachukwu, J. C., (2018). "Fighting Terrorism: Empirics on Policy Harmonisation", German Economic Review, 19(3), pp. 237-259.

Asongu, S. A., Tchamyou, V. S., Minkoua, N, J. R., Asongu, N., \& Tchamyou, N. P., (2018a). "Fighting terrorism in Africa: Benchmarking policy harmonization", Physica A: Statistical Mechanics and its Applications, 492(February), pp. 1931-1957.

Asongu, S. A., Tchamyou, V. S., Asongu, N., \& Tchamyou, N. P., (2018b). "Fighting terrorism in Africa: evidence from bundling and unbundling institutions", Empirical Economics. DOI: 10.1007/s00181-017-1378-3.

Bandyopadhyay, S., Sandler, T., \&Younas, J., (2014). "Foreign direct investment, aid, and terrorism", Oxford Economic Papers, 66(1), pp. 25-50.

Bandyopadhyay, S., \& Younas, J., (2014), “Terrorism: A Threat to Foreign Direct 
Investment", Doing Business Abroad Policy Report

https://www.stlouisfed.org/ /media/Files/PDFs/publications/pub_assets/pdf/re/2014/d/terroris m.pdf (Accessed: 29/04/2015).

Banuri, T., (2013). "Sustainable Development is the New Economic Paradigm", Development, 56(2), pp. 208-217.

Beets, S. D., (2005). "Understanding the Demand-Side Issues of International Corruption." Journal of Business Ethics, 57 (1), pp. 65-81.

Billger, S. M., \& Goel, R. K., (2009), "Do existing corruption levels matter in controlling corruption? Cross-country quantile regression estimates", Journal of Development Economics, 90(2), pp. 299-305.

Biscaye, P., Harris, K. P., Reynolds, T., \& Anderson, C. L., (2015). "Relative Effectiveness of Bilateral and Multilateral Aid on Development and Social Outcomes", Evans School of Policy Analysis and Research (EPAR) Brief No. 294, Seattle, Washington.

Black, D., (1990). The elementary forms of conflict management. New York, Plenum Press.

Boateng, A., Asongu, S. A., Akamavi, R., \& Tchamyou, V. S., (2018). "Information Asymmetry and Market Power in the African Banking Industry", Journal of Multinational Financial Management, 44, (March), pp. 69-83.

Borg, M. J., (1992). "Conflict management in the modern world-system". Sociological Forum, 7(2), pp. 261-282.

Brambor, T., Clark, W. M., \& Golder, M., (2006), "Understanding Interaction Models: Improving Empirical Analyses", Political Analysis, 14 (1), pp. 63-82.

Brockhoff, S., Kieger, T., \& Meierrieks, D., (2015). "Great Expectations and Hard Times The (Nontrivial) Impact of Education on Domestic Terrorism", Journal of Conflict Resolution, 59(7), pp. 1186-1215.

Caulderwood, K., (2015) "Sub-Saharan Africa Falls Behind In Fight Against Extreme Poverty: World Bank Report”, International Business Times (April 14th 2015). http://www.ibtimes.com/sub-saharan-africa-falls-behind-fight-against-extreme-povertyworld-bank-report-1881460 (Accessed: 19/04/2015).

Choi, S-W., (2015). "Economic growth and terrorism: domestic, international, and suicide", Oxford Economic Papers, 67(1), pp. 157-181.

Choi, S-W., (2010). "Fighting Terrorism through the Rule of Law?", The Journal of Conflict Resolution, 54(6), pp. 940-966.

Choi, S-W., \& Salehyan, I., (2013). "No Good Deed Goes Unpunished: Refugees, Humanitarian Aid, and Terrorism", Conflict Management and Peace Sciences, 30(1), pp. 5375. 
Costa, A., Hermandez, M., \& Sebastian-Gallés, N., (2008). "Bilingualism aids conflict resolution: Evidence from the ANT task", Cognition, 106 (1), pp. 59-86.

Efobi, U., \& Asongu, S., (2016). "Terrorism and capital flight from Africa", International Economics, 148(December), pp. 81-94.

Efobi, U., Asongu, S., \& Beecroft, I., (2015). "Foreign Direct Investment, Aid and Terrorism: Empirical Insight Conditioned on Corruption Control”, African Governance and Development Institute Working Paper No. 15/007, Yaoundé.

Enders, W., \& Sandler T., (2006). The Political Economy of Terrorism. New York: Cambridge University Press.

Eubank, N., (2012), "Taxation, Political Accountability and Foreign Aid: Lessons from Somaliland", Journal of Development Studies, 48(4), pp. 465-480.

Feridun, M., \& Shahbaz, M., (2010). "Fighting Terrorism: Are Military Measures Effective? Empirical Evidence from Turkey”, Defence \& Peace Economics, 21(2), pp. 193-205.

Foster, P., (2014). "Jihadists from around the world flock to fight with Isil; UN", The Telegraph.

http://www.telegraph.co.uk/news/worldnews/islamic-state/11200701/Jihadists-from-aroundthe-world-flock-to-fight-with-Isil-UN.html (Accessed: 12/03/2015).

Gaibulloev, K., \& Sandler, T., (2009). "The impact of terrorism and conflicts on growth in Asia”, Economics and Politics, 21(3), pp. 359-383.

Gardner, K. L., (2007). "Fighting Terrorism the FATF Way". Global Governance: A Review of Multilateralism and International Organisation, 13(3), pp. 325-345.

Ghosh, J., (2013). “Towards a Policy Framework for Reducing Inequalities", Development, 56(2), pp. 218-222.

GTI (2014). "Global Terrorism Index: Measuring and Understanding the Impact of Terrorism", Institute for Economics and Peace, pp. 2-90.

http://www.visionofhumanity.org/sites/default/files/Global\%20Terrorism\%20Index\%20Repor t\%202014_0.pdf (Accessed: 28/04/2015).

Gries, T., Krieger, T., \& Meierrieks, D., (2011). "Causal Linkages Between Domestic Terrorism and Economic Growth”, Defence and Peace Economics, 22(5), pp. 493-508.

Gyimah-Brempong, K., \& Racine, J. S. (2014). “Aid and Economic Growth: A Robust Approach”, Journal of African Development, 16(1), pp. 1-35.

Heyneman, S. P., (2002). "Defining the Influence of Education on Social Cohesion", International Journal of Educational Policy, Research and Practice, 3(4), pp. 73-97.

Heyneman, S. P., (2008a). "Education, social cohesion and ideology. In Right to Education: Policies and Perspectives, edited by Emin Karip, 89-104. Ankara: Turkish Education 
Association.

Heyneman, S. P., (2008b). "Buying your way into Heaven: The corruption of education systems in global perspective.”, Perspectives on Global Issues, 2 (1), pp. 1-8.

Hoffman, A. M., Shelton, C., \& Cleven, E., (2013). "Press Freedom, Publicity, and the CrossNational Incidence of Transnational Terrorism", Political Research Quarterly, 66 (4), pp. 896-909.

Humphreys, M., (2005). "Natural Resources, Conflict, and Conflict Resolution. Uncovering the Mechanisms", Journal of Conflict Resolution, 49 (4), pp. 508-537.

International Country Risk Guide. (2010) The political risk services group, available at http://www.prsgroup.com/icrg.aspx (Accessed 10 October 2010).

Johnson A., \& Quartey P (2009), "Foreign Aid and Human Development Indicators in subSaharan Africa", Journal of Developing Societies, 25(1), pp. 57-83.

Kargbo, P. M., \& Sen, K., (2014). "Aid Categories that Foster Pro-Poor Growth: The Case of Sierra Leone”, African Development Review, 26(2), pp. 416-429.

Kelsey, D., \& le Roux, S., (2017), "Dragon Slaying with Ambiguity: Theory and Experiments", Journal of Public Economic Theory, 19(1), pp. 178-197.

Kelsey, D., \& le Roux, S., (2018). "Strategic Ambiguity and Decision-making An Experimental Study", Theory and Decision, 84( 3), pp 387-404.

Klobodu, E. K. M., \& Adams, S., (2016). "Capital Flows and Economic Growth in Ghana," Journal of African Business, 17(3), pp. 291-307.

Koenker, R., \& Hallock, F.K., (2001), “Quantile regression”, Journal of Economic Perspectives, 15(4), pp.143-156.

Koh, W. T. H., (2007). "Terrorism and its impact on economic growth and technological innovation", Technological Forecasting and Social Change, 74(2), pp. 129-138.

Krause, U., (2013). "Innovation: The new Big Push or the Post-Development alternative?", Development, 56(2), pp. 223-226.

Kumi, E., Muazu I., \& Yeboah, T., (2017). “Aid, Aid Volatility and Sectoral Growth in SubSaharan Africa: Does Finance Matter?," Journal of African Business, 18(4), pp. 435-456.

Marglin, S. A., (2013). “Premises for a New Economy”, Development, 56(2), pp. 149-154.

Meierrieks, D., \& Gries, T., (2013). "Causality between terrorism and economic growth", Journal of Peace Research, 50(1), pp. 91-104. 
Monni, S., \& Spaventa, A., (2013). "Beyond GDP and HDI: Shifting the focus from paradigms to politics”, Development, 56(2), pp. 227-231.

Nyasha, S., \& Odhiambo, N. M., (2017). "Banks, Stock Market Development and Economic Growth in Kenya: An Empirical Investigation," Journal of African Business, 18(1), pp. 1-23.

Obeng-Odoom, F. (2013). “Africa's Failed Economic Development Trajectory: A Critique”, African Review of Economics and Finance, 4(2), pp. 151-175.

Öcal, N., \& Yildirim, J., (2010). "Regional effects of terrorism on economic growth in Turkey: A geographically weighted regression approach”, Journal of Peace Research, 47(4), pp. 477-489.

Okada, K., \& Samreth, S.,(2012), "The effect of foreign aid on corruption: A quantile regression approach", Economic Letters, 115(2), pp. 240-243.

Oreopoulos, P., \& Salvanes, K. G., (2009). "How Large are Returns to Schooling? Hint: Money Isn't Everything.”, NBER Working Paper No. 15339, Massachusetts.

Piazza, J. A., (2006). "Rooted in Poverty?: Terrorism, Poor Economic Development, and Social Cleavages", Terrorism and Political Violence, 18(1), pp. 159-177.

Quartey P., \& Afful-Mensah, G., (2014), Foreign Aid to Africa: Flows, Patterns and Impact, in Monga C and Lin J (eds), Oxford Handbook of Africa and Economics, Volume 2: Policies and Practices, Oxford University Press, Oxford, UK.

Rodrik, D., (2008). “The Real Exchange Rate and Economic Growth”, Harvard University, http://www.hks.harvard.edu/fs/drodrik/Research\%20papers/RER\%20and\%20growth.pdf (Accessed: 29/04/2015).

Shahbaz, M., Shahbaz, S., M., Nasir, M. M., \& Edward, W. M., (2013). "An analysis of a causal relationship between economic growth and terrorism in Pakistan", Economic Modelling, 35(September), pp. 21-29.

Shahzad, S. J. H., Zakaria, M., Rehman, M. U., Ahmed, T., \& Fida, B. A., (2015)

"Relationship Between FDI, Terrorism and Economic Growth in Pakistan: Pre and Post 9/11 Analysis", Social Indicators Research, (March, 2015) http://link.springer.com/article/10.1007\%2Fs11205-015-0950-5

Singh, P., (2001). "Punjab Terrorism: Truth Still Uncovered", Economic and Political Weekly, 36 (40), pp. 3829-3831.

Singh, P., (2007). "The Political Economy of the Cycles of Violence and Non-violence in the Sikh Struggle for Identity and Political Power: implications for Indian federalism", Third World Quarterly, 28(3), pp. 555-570.

Straus, S., (2012). "Wars do end. Changing Patterns of Political Violence in Sub-Saharan Africa", African Affairs, 111(443), pp. 179-201. 
Tchamyou, S. A., \& Asongu, S. A., (2017). "Conditional market timing in the mutual fund industry", Research in International Business and Finance, 42(December), pp. 1355-1366.

Titumir, R. A. M., \& Kamal, M. (2013). “Growing Together Sustainably: A zero-poverty post 2015 development framework”, Development, 56(2), pp. 172-184.

Thomas, K.W., (1992). Conflict and negotiation processes in organisations. In: Dunnette, M.D. and L.M. Hough eds. Handbook of industrial and organisational psychology. Palo Alto, CA, Consulting Psychologists Press. pp. 651-717.

Volkema, R. J., \& Bergmann, T. J., (1995). “Conflict styles as indicators of behavioural patterns in interpersonal conflicts”. The Journal of Social Psychology, 135 (1), pp. 5-15.

Wamboye, E., Adekola, A., \& Sergi, B. S. (2013). "Economic Growth and the Role of Foreign Aid in Selected African Countries", Development, 56(2), pp. 155-171.

World Bank (2015). “World Development Indicators', World Bank Publications http://www.gopa.de/fr/news/world-bank-release-world-development-indicators-2015 (Accessed: 25/04/2015). 